\title{
WILLIAM G. MORROW: A BENCH WITH A VIEW
}

\author{
JAN ALEXANDER SMITH* \\ and SHERRILYNN J. KELLY**
}

The late Mr. Justice William G. Morrow rose to become one of the most significant figures in Alberta's legal history. On the tenth anniversary of his passing, the authors reflect upon and examine the roots, the career and the contributions of this outstanding Albertan.
Feu M. le juge William G. Morrow devint l'une des figures les plus importantes de l' histoire juridique de l'Alberta. A l'occasion du dixième anniversaire de sa mort, les auteurs examinent quels furent la carriere et la contribution de cet Albertain exceptionnel.

\section{TABLE OF CONTENTS}

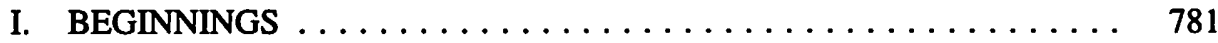

II. WORLD WAR II $\ldots \ldots \ldots \ldots \ldots \ldots \ldots \ldots \ldots \ldots \ldots \ldots \ldots \ldots \ldots \ldots \ldots$

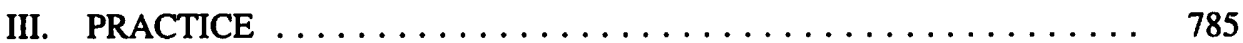

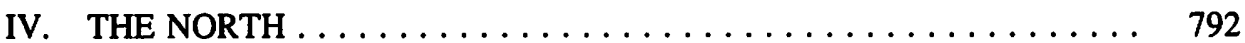

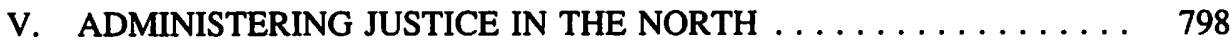

A. CONSTITUTIONAL $\ldots \ldots \ldots \ldots \ldots \ldots \ldots \ldots \ldots \ldots \ldots \ldots \ldots$

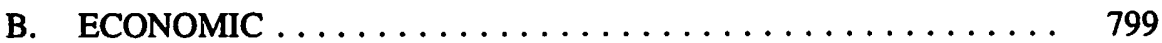

C. CULTURAL ...................... 800

1. Marriage and Adoption .................. 800

2. Hunting and Fishing Rights $\ldots \ldots \ldots \ldots \ldots \ldots \ldots \ldots, 802$

3. Land Claims ...................... 805

4. Discriminatory Laws $\ldots \ldots \ldots \ldots \ldots \ldots \ldots \ldots \ldots . \quad 807$

D. PHILOSOPHY $\ldots \ldots \ldots \ldots \ldots \ldots \ldots \ldots \ldots \ldots \ldots \ldots \ldots$

1. Independence of the Court $\ldots \ldots \ldots \ldots \ldots \ldots \ldots \ldots, 810$

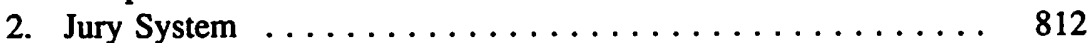

3. Discretion in Sentencing $\ldots \ldots \ldots \ldots \ldots \ldots \ldots \ldots .613$

E. INQUIRIES $\ldots \ldots \ldots \ldots \ldots \ldots \ldots \ldots \ldots \ldots \ldots \ldots \ldots \ldots \ldots \ldots$

VI. ENDINGS $\ldots \ldots \ldots \ldots \ldots \ldots \ldots \ldots \ldots \ldots \ldots \ldots \ldots \ldots \ldots$

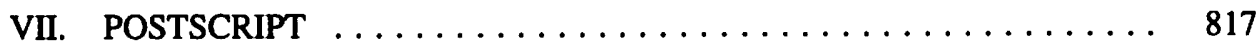

Many who enter the legal profession make a mark, but few leave an enduring legacy. The late Mr. Justice William G. Morrow left such a legacy. Numerous cases in which he was involved, both as a lawyer and later as a judge, dealt with novel and sometimes perplexing issues, required innovation in interpreting and applying the law, and

Jan Alexander Smith is at present articling with the Court of Queen's Bench and the Court of Appeal of Alberta in Edmonton. She will complete her articles with the law firm of Emery Jamieson.

- Sherrilynn J. Kelly is at present articling with the Court of Queen's Bench and the Court of Appeal of Alberta in Calgary. She will complete her articles with the law firm of Code Hunter. 
contributed greatly to the development of our case law. Justice Morrow ${ }^{1}$ was also a chronicler of the times and circumstances of which he was a part through his contributions to legal journals and the many speeches which he wrote and delivered. The legacy he has left is the manifestation of his belief in justice, his respect for the rule of law, his commitment to the legal profession and the people it serves, and his compassion, all of which underlay his life's work. ${ }^{2}$

1. A biography, generally speaking and logically so, begins with the individual's birth and chronicles that person's life onward. This biography is no exception. Notwithstanding that it was some years after his birth that Justice Morrow was appointed to the bench, the authors have chosen to refer to him as such throughout the article.

Through personal meetings, telephone conversations, and correspondence, the authors have had the opportunity to speak with many of the people who knew Justice Morrow. All of the conversations, with the permission of the persons involved, were tape recorded and subsequently transcribed. This was done to ensure that their memories, recollections, and reflections were accurately described. Although questions were sometimes submitted in advance, they were not intended to restrict the scope of the discussion. The authors take complete responsibility for any inaccuracies.

The authors are indebted and grateful to the many people who so willingly shared their memories and assisted in infusing some of Justice Morrow's vitality into the chronology of events and cases: Judge Marjorie M. Bowker, Dean Wilbur F. Bowker, Mr. Justice Andre M. Dechene; The Honourable M.M. de Weerdt, Justice of the Supreme Court of the Northwest Territories; Mr. Robert P. Engle; His Honour Chief Judge R. W. Halifax, Territorial Court of the Northwest Territories; Mr. W. H. Hurlburt, Q.C.; The Honourable J. H. Laycraft, Chief Justice of Alberta; Mr. Kenneth A. McKenzie; Mrs. Genevieve Morrow; Judge Peter B. Parker; Mr. G. Brian Purdy, Q.C.; Mr. D.V. Reynolds, Q.C.; Mr. David H. Searle, Q.C.; The Honourable Wm. A. Stevenson, Justice of the Supreme Court of Canada; The Honourable C. F. Tallis, Justice of the Court of Appeal of Saskatchewan; Mr. Everett Tingley; Judge 0.J.T. Troy; and The Right Honourable John N. Turner.

The authors would also like to express their appreciation to the following people without which this project would have been much more difficult: The Alberta Law Review; Joan D. Bilsland; Dr. J.W. Bilsland, Professor Emeritus, Department of English, University of Alberta; Professor R.D. Gibson, Visiting Professor, Faculty of Law, University of Alberta; Professor Frank D. Jones, Faculty of Law, University of Alberta; Ms. Olga Kizlyk, Law Library, Faculty of Law, University of Calgary; Ms. Lillian MacPherson, Law Librarian, Faculty of Law, University of Alberta and her invaluable staff; Ms. A.L. Steele, Special Collections, MacKimmie Library, University of Calgary; and Brendan J. Vickery.

Justice Morrow's personal papers. including an unpublished autobiography, which he left to the University of Calgary, were made available to the authors through an inter-library loan. Many of these papers, particularly the manuscript of his autobiography, have been relied upon extensively in preparing this biography. Among Justice Morrow's papers is a compilation of newspaper, magazine, and other periodical articles which he collected for nearly fifty years. These materials, among other things, helped to acquaint the authors with the times in which Justice Morrow lived. Many of the articles have been relied upon in the course of the biography. Accordingly, information which would normally be found in footnotes is lacking. 


\section{BEGINNINGS}

William George Morrow was born at home on February 5, 1917, to William and Opal Morrow. His Christian name, William, was in keeping with a family tradition; the eldest son was always so named. ${ }^{3}$

Justice Morrow's Irish ancestry is believed to have played some role in his life, as revealed in his sense of adventure, his imagination, his delight in a challenge, and his relish in getting his point across. The luck of the Irish may have also had a hand. In any event, these characteristics typify Justice Morrow's life.

Justice Morrow's father had been a teacher before becoming a lawyer. Mr. Morrow, Sr. had not gone to university; he had gained admission to the bar after completing a five-year clerkship. Law was not, however, the lucrative practice that many envision it to be today: a contemporary of Justice Morrow's recalls that many lawyers at the time earned less than barbers. ${ }^{4}$

While the Morrow family made their home in Edmonton, urbanization had not reached the area in which they lived. Like many people of the time, they relied on their agrarian backgrounds and ingenuity to supplement their resources: they gardened, hunted, and even foraged for discarded building materials for fuel.

From his early childhood, Justice Morrow had a penchant for the outdoors. As he reminisced, at the 60th anniversary of his high school: ${ }^{5}$

In my days - the 1920's and 1930's - at Westmount, it was a new and modern school built on the north-west edge of a growing City. It was on the edge of the built-up area, almost surrounded by bush and grassland. ... I liked the bush so close at hand. You could play in it at recess, and on the [A]rbour [D]ay clean-up you could do a disappearing act and sneak home.

He spent hours hunting, gathering bird eggs, building tree forts, lighting grass fires in the spring, exploring, playing games -- and doing chores. There were also many summers spent working on relatives' farms in Manitoba. As he grew older, Justice Morrow assisted his father both as an office boy and a secretary of sorts. He was also known to help his father's clients in the field.

Justice Morrow's early academic career was hardly noteworthy. His misbehaviour warranted discipline on many an occasion. As he recalled: ${ }^{6}$

In one month ... I remember winning the class record - the strap once every day, and one day - twice. As I look back, I wonder how some of us got through. And there was no use me complaining at home that perhaps a teacher might be picking on me. My father had been a teacher before he became a lawyer. The teacher could do no wrong. I would only get a double dose if it got out at home that I had been a bad boy at school.

3. Interview with Mr. D.V. Reynolds, Q.C. (23 November 1989).

4. Interview with Mr. K.A. McKenzie (5 October 1989).

5. William G. Morrow, "Westmount's 60th Anniversary" (Address to Alumni, Edmonton, Alberta, 4 May 1973) [unpublished].

6. Ibid. 
Notwithstanding his early exposure to the law, it would be mistaken to surmise that Justice Morrow's decision to go to law school, or even to university, was a foregone conclusion. He described himself as less a than diligent or serious student. It was not until the latter years of high school that his appetite for reading became a passion which whetted his desire to learn.

While it does not appear that Justice Morrow was ever pressured into choosing law as a career, he nonetheless enrolled in the combined arts and law program at the University of Alberta in 1934. His decision to pursue the study of law was motivated, at least in part, by his friend, Robert E. Folinsbee, who had achieved a higher score than he did on their first year geology final. ${ }^{7}$ Geology had, until then, been a preoccupation of Justice Morrow's.

The law school, unlike the comfortable surroundings which exist today, consisted of two rooms on the 2 nd floor of the Arts Building. One room contained the library and served the second and third year students, while the other room was used by the first year students. Because space was so limited, students often had to go elsewhere when a lecture was being given or endure the lecture while they tried to study. There were only two full-time professors: Dean J.A. Weir and Professor M.M. Mclntyre. The class of 1939 consisted of only nineteen students which was by no means uncommon for the time. ${ }^{8}$ Justice Morrow has been variously described by his classmates as having been "unobtrusive", "self-effacing", "a hard worker", and "a very serious chap".

Justice Morrow did not participate in the social life at university. While school was presumably more enticing than it had been in his youth, he was also very shy. Justice Morrow did serve as the Editor of the Gateway, the student newspaper, and rescued it from debt. ${ }^{9}$ He was also the Business Manager of the predecessor to the Alberta Law Review, the Alberta Law Quarterly, for two years. Such business acumen, however, would not carry over to his days in practice.

With the worldwide depression of the thirties giving way to the second World War, the class of 1939 graduated into an uncertain world. Even Justice Morrow expressed doubts about a future in law.

Justice Morrow graduated with distinction. ${ }^{10}$ Whether or not it was the result of a scarcity of articling positions or the fact that Mr. Morrow, Sr. was a lawyer, he served his articles of clerkship with his father. Justice Morrow was admitted to the bar on June 14,

Interview with Mrs. Genevieve Morrow (23 November 1989 and 19 January 1990).

Interview with Judge Marjorie M. Bowker (12 September 1989); supra, note 4.

Supra, note 7.

Justice Morrow received his Bachelor of Arts degree in 1938 and his Bachelor of Laws degree in 1939. He was also the recipient of the Sydney B. Woods Memorial Prize in Constitutional Law. Justice Morrow was awarded three honourary degrees: Dalhousie University 1972, The University of Alberta 1974, and The University of Calgary 1975. 
1940, before the late Mr. Justice W.C. Ives who had admitted his father twenty-five years earlier. ${ }^{11}$

Mr. Morrow, Sr. was a solicitor. His practice has been described as a modest one, consisting of a great deal of conveyancing and foreclosures, which undoubtedly reflected the times. Justice Morrow, however, was determined by all accounts to practise law in all its facets. As a result, his father agreed that he could take any case without regard to the client's means. In contrast, however, Justice Morrow only allowed himself five years within which to be clearing $\$ 100.00$ a month or he would quit practising law. ${ }^{12}$ The need for financial security, in the midst of such uncertain times, was a concern shared by many.

Early practice was neither personally nor remuneratively rewarding. As a beginning lawyer, Justice Morrow had no clients of his own. Times being such, there was little work and one took what was available. Lawyers also found themselves doing things which are probably unheard of today. Under The Farmers' Creditors Arrangement $A c t,{ }^{13}$ farmers were entitled to defer interest payments if they could demonstrate that their income was below a certain level. Once, in an attempt to measure how much grain a farmer had harvested that year, Mr. Morrow, Sr. was confronted by a farmer wielding a pitchfork. Justice Morrow's response was to fetch and load a shotgun to force the farmer to stand back while his father carried on with his work. On another occasion, a farmer who was unable to get the help he needed to take his crop off, called upon Mr. Morrow, Sr. for help. Justice Morrow was enlisted to hay and work on the threshing machine. ${ }^{14}$

\section{WORLD WAR II}

Like many men of his generation, Justice Morrow felt the despair which was engulfing Europe by the early forties and decided to enlist. His desire to serve his country is evidenced by the fact that in his haste to see duty he applied to all three services. While waiting to be called up, he joined the Second Battalion Edmonton Fusiliers which was a militia unit. Justice Morrow had already received his Captain's certificate in the Canadian Officers' Training Corps during his time at university. That, however, was of no avail when Justice Morrow applied for officers' training. He made a number of attempts to speed up the process by prevailing on both the army and navy to hurry his application on.

Eventually, in April of 1942, he was appointed a Probationary Sub-Lieutenant (Temporary) of the Royal Canadian Naval Volunteer Reserve (R.C.N.V.R.) for duty with

II.

The Edmonton Journal (19 June 1940); The Edmonton Bulletin (19 June 1940). Justice Morrow was also admitted to the bar in the Northwest Territories, British Columbia, and the Yukon Territory in 1959,1961 , and 1962 , respectively.

12. Supra, note 7.

13. S.C. 1943-44, c. 26. This incident occurred when Mr. Morrow, Sr., who was acting for a mortgagee, was carrying out an inspection and measurement as he was entitled to do under the mortgage: Letter from The Honourable Wm. A. Stevenson, Justice of the Supreme Court of Canada to Sherrilynn J. Kelly and Jan Alexander Smith (29 June 1990).

14. 
the Edmonton Division. ${ }^{15}$ Subsequently, he received his appointment to His Majesty's Canadian ships the Nonsuch and Kings for training. ${ }^{16}$ In February of 1943 he was appointed Sub-Lieutenant to the H.M.C.S. Georgian and later promoted to Lieutenant in the fall of that year. ${ }^{17}$

While serving on the Georgian, a minesweeper, Justice Morrow had the opportunity to experience history in the making: in November of 1943 the Georgian was the first Canadian ship to refuel a plane at sea. Justice Morrow oversaw the seamen who were assigned to handle the refuelling. ${ }^{18}$ Only a month before, the Georgian had rescued ten American army fliers who had drifted in rubber rafts for eighteen hours in the North Atlantic after their plane had crashed. Justice Morrow observed their flare as he stood watch while the Georgian was escorting a tanker with airplane fuel to Gander, Newfoundland. ${ }^{19}$ He also ingeniously captured this period of history in photographs and film: a careful examination of the Fleet Orders revealed that an officer could be issued a photography permit on the recommendation of his Captain.

The Georgian was one of sixteen Canadian minesweepers that was sent overseas in February of 1944. Attached to the Fourteenth Minesweeping Flotilla, it was one of two ships commended for "loyal and devoted" service. The Georgian, as the lead minesweeper, was the first Canadian ship to dispose of a mine when it began its sweeps on June 4, 1944. It was the first of eleven mines swept during the flotilla's assault. The Georgian, however, had the greatest number to her credit -- six in all. ${ }^{20}$ After the Normandy invasion on D-Day, the Georgian spent most of its time involved in routine minesweeping.

Following the Georgian's return to Halifax in 1945, Justice Morrow re-enlisted. He was on the frigate Carlplace, ${ }^{21}$ which was preparing to go to the Pacific theatre, when the Japanese surrender was announced.

Justice Morrow so enjoyed his time in the "wavy navy", so called for its wobbly rank stripes, that he was tempted to re-enlist after the war was over, even though he could not swim a stroke. Mr. Morrow, Sr., however, had carried on the practice in Justice Morrow's absence with some risk to his health. This undoubtedly exerted considerable influence on Justice Morrow's decision to return to the practice.

After three and a half years of service in the R.C.N.V.R., Justice Morrow was placed on the retired list and resumed practice as a partner in the law firm of Morrow \& Morrow. In January of 1946, Justice Morrow was one of a number of Albertans who

\footnotetext{
15. Appointment, Department of National Defence (7 May 1942).

16. Appointment, Department of National Defence and Naval Service (6 November 1942).

17. Appointments, Department of National Defence and Naval Service (8 March 1943 and 2 October 1943).

18. The Sherbrook Daily Record (24 November 1945).

i9. The Edmonton Bulletin (20 October 1943); The Calgary Albertan (20 October 1943).

20. The Evening Telegram (22 December 1944).

21. Appointment, Department of National Defence and Naval Service (27 June 1945).
} 
were honoured by King George V in his New Year's Honours List: he was Mentioned in Dispatches. His citation read, in part, "[d]uring this time he showed unequaled resource, outstanding zeal, leadership and devotion to duty."22

What impact "the war to end all wars" has on an individual is perhaps best left to that person. Yet one cannot help but think that its effect was enduring. Although not considered a fatalist by any, Justice Morrow did not expect to be alive at the end of D-Day. As a contemporary of Justice Morrow's has said, "you have to have courage, dedication, and resolve to go ahead and do a thing like that, knowing that you are probably going to be killed in a couple of hours and still get out there and exude confidence." 23

\section{PRACTICE}

One is not born with a sense of justice; it is something which is learned. The adversity which Justice Morrow witnessed during both the Depression and the War undoubtedly helped to shape his concept of justice and enhance his compassion for other people. One of Justice Morrow's colleagues recalls that "[he believed] there was a thing called a system of justice in the courts, and people were entitled to go there, and if they couldn't afford it, then it was up to the people who ran the system, the lawyers and judges and so on, to make sure these people had a hearing. ${ }^{24}$ His penchant for taking unprofitable and unpopular cases was widely known, and there is some speculation that other lawyers may have taken advantage of this. ${ }^{25}$ Justice Morrow's interest in the law, as a discipline, as well as its development, is also believed to have motivated this inclination. In the days before Legal Aid this was no small sacrifice; one still had to make a living. ${ }^{26}$

Justice Morrow was often heard to say, "law is not a business, it's a profession." Mr. Morrow, Sr. recognized his son's apparent lack of business acumen early on. A partner of Justice Morrow's remembers Mr. Morrow, Sr. coming to the office one day and saying, as he shook his head, "you stick with Bill, you look after the money and let him look after the courthouse." Mr. Morrow, Sr. was appalled at how much work his son took for practically nothing. ${ }^{27}$

In a similar vein, the tax department's explanation for auditing the firm on one occasion was, "well, your income is so much lower than any other law firm ... we had to feel that some money was being hidden." After being shown a file on which several thousands of dollars' work had been done, for which the client had been billed only $\$ 5.00$,

\footnotetext{
22. Unidentified newspaper article.

23. Supra, note 3.

24. Ibid.

25. This phenomenon is alluded to by Justice Morrow in "Some Legal Legends" (1986) 25th Anniversary Issue Alta. L. Rev. 15 at 21.

26. Justice Morrow helped to establish the first Legal Aid system in Alberta in 1964. Legal counsel was made available, on a voluntary basis, to all persons accused of serious crimes. The system was first conducted on a trial basis in Edmonton. Having been judged a success, the system was expanded to other centres. Supra, note 3.
} 
together with an invitation to review any of Justice Morrow's other files, the department immediately discontinued its audit. ${ }^{28}$

Billing quotas, long-range forecasts, charging clients interest on unpaid bills, expensive leasehold improvements and the like would be an anathema to Justice Morrow. While it may be unfair to compare the practice of law today with that of yesterday, many of Justice Morrow's contemporaries nevertheless lament these changes. There is little doubt that if Justice Morrow were practising today, he would be a sole practitioner or in a small firm with people who shared his views or, as some might say, where he could "call the shots".

The collegiality of the early Alberta bar, no doubt owing to its size, together with what Justice Morrow perceived as the favourable treatment returning veterans received, permitted relatively inexperienced lawyers to gain acceptance and stature somewhat earlier than that experienced today. There was a certain camaraderie which many of Justice Morrow's contemporaries see lacking in the bar today. Sheer numbers, of course, necessitate a certain loss of intimacy.

The Legal Forum, which persists today, best exemplified this camaraderie. Mr. Justice Andre M. Dechene remembers how it all began: ${ }^{29}$

\begin{abstract}
We used to meet for coffee, as young lawyers almost every morning. ... There had been a legal discussion club, ... that used to meet once a month and deliver learned papers to each other and discuss things. Bill and I one day said why don't we start a club of our own. We took a paper serviette and made a list of fellows that we felt would be congenial. It was a most undemocratic way of starting a club. We began to meet once a month and deliver papers. There was one criteria -- we didn't take Queen's Counsel, or any judges.
\end{abstract}

Needless to say, the membership rules were changed over time. ${ }^{30}$

The strict discipline with which he was raised, coupled with that instilled in the navy, affected Justice Morrow in two ways. First, it enhanced his ability to withstand the long hours a fledgling, and later successful, practice required, as well as that of a judgeship. Second, and perhaps more fundamentally, it allowed him to face the challenges of litigation which his innate shyness might otherwise have undermined.

Case law not only states the law, it reflects our history. Political and economic issues underlie many cases just as changes in our mores and values are also mirrored. Every litigator, at least to some extent, has played a part in shaping our laws and our history.

Dearing v. Herbert, ${ }^{31}$ or as he described it, "widow goes to the Supreme Court on death of her son -- I finance the case", is an instance of Justice Morrow acting for a client, who, he believed, deserved the opportunity to be heard regardless of recompense. At trial, the deceased, who had been walking on a highway, had been found one-third

31. [1957] S.C.R. 843, rev'g (1957), 22 W.W.R. (N.S.) 455, 9 D.L.R. (2d) 697 (Alta. S.C.A.D.). 
contributorily negligent. On appeal, however, the deceased was found to have been entirely at fault. The trial judgment was restored, subject to a modification in damages, by the Supreme Court of Canada. While the case can hardly be said to have broken new ground, it exemplifies the undertaking Justice Morrow made when he first began practice. It is also but one example of the motor vehicle litigation in which he was involved during his career.

In Joncas v. Pennock, ${ }^{32}$ Justice Morrow agreed to act for the plaintiff who was trying to recover her late father's property from his lawyer. Mrs. Joncas had brought the suit herself and in her own name. As a result, the lawyer, whom she had retained just before trial, was unable to prevail. No one would take the appeal. While Mrs. Joncas maintained publicly that no one would help her because she was trying to sue a lawyer, apparently she was not an ideal client. Nonetheless, Justice Morrow appealed the decision; he was not successful before the Court of Appeal or on an application for leave before the Supreme Court of Canada. The case, however, resolved jurisdiction only, as Justice Morrow intended. Since there had not been a hearing on the merits, Justice Morrow instituted proceedings again, properly, and ultimately prevailed throughout several motions, at trial, and on appeal. ${ }^{33}$

The Alberta oil boom brought with it litigation which presented many new issues. It also reaffirmed one of Justice Morrow's basic tenets in practice: do a good job for your client and he will come back, perhaps with others. Many of his father's clients were farmers in the Edmonton area. With oil companies approaching them to enter into oil and gas leases, the farmers brought their business to the firm.

One such client brought Justice Morrow what he considered to be his first "big case", commonly known as "the Sand and Gravel case". ${ }^{34}$ As a result of the oil discovery at Redwater, farmers engaged in the lucrative practice of selling sand and gravel for wellsite service roads and for building materials in the emerging construction industry. The oil company, in whose favour there were reservations on the farmers' titles, intervened claiming ownership of the sand and gravel.

Although Justice Morrow lost at trial on the issue of whether sand and gravel was a mineral or valuable stone or simply part of the soil, he prevailed both in the Court of Appeal and in the Supreme Court of Canada. His argument was deceptively simple: when all mines, minerals, and valuable stone had been reserved in the original titles, no one was concerned about the sand and gravel; it was just part of the soil.

While the case was pending appeal, the Alberta Legislature enacted The Sand and Gravel Act. Justice Morrow's argument that sand and gravel belonged to the surface

32. (1958), 24 W.W.R. (N.S.) 325 (Alta. S.C.T.D.) aff'd (1959), 27 W.W.R. (N.S.) 174 (Alta. S.C.A.D.).

33. Joncas v. Pennock (No. 2) (1961), 37 W.W.R. (N.S.) 134 (Alta. S.C.T.D., affd Alta. S.C.A.D.).

34. Justice Morrow also acted for another farmer who was sued by the oil company. The two actions were tried together: Western Minerals Ltd. v. Gaumont and Western Minerals Ltd. v. Brown, [1953] 1 S.C.R. 345, aff'g (1951), 3 W.W.R. (N.S.) 434 (Alta. S.C.A.D.), rev'g (1951), 1 W.W.R. (N.S.) 369 (Alta. S.C.T.D.). 
owner was now the law. When a similar dispute was brewing over clay and marl a few years later, Justice Morrow armed his farming clients with a letter to present to the government. Legislation was again enacted; clay and marl also belonged to the owner of the surface. ${ }^{35}$

One of Justice Morrow's most cherished memories was his opportunity to take a case to the Judicial Committee of the Privy Council -- in fact, it was the last case heard on appeal from Canada. ${ }^{36}$ Justice Morrow's client had lost at trial, succeeded on appeal, and lost again before the Supreme Court of Canada. Not to be deterred, however,

... Bill looked at the pleadings and saw that the Statement of Claim had been issued on December 5 , 1949. The cut-off date for the Privy Council was December 7, 1949. Bill was a stubbom man and persistent and so we went off to the Privy Council to do what turned out to be the last case. That was a very interesting experience with Bill. We persevered before the five Privy councillors, Viscount Simmonds led the panel and the junior councillor... was Lord Denning... but a case that had taken ... about $11 / 2$ hours to try ... about $3 / 4$ of a day in the Alberta Court of Appeal and ... almost a day in the Supreme Court of Canada, took 4 1/2 days in the Privy Council. ${ }^{37}$

The case was a "first" ${ }^{38}$ as well. Viscount Simmonds suggested that in the oppressive heat, "you might like to rid yourselves of the encumbrance of your wigs" ${ }^{13}$ and so counsel doffed their headgear for the first time before the Privy Council. Justice Morrow, however, insisted on wearing his wig for some time because "he had not come all that distance to be cheated out of the opportunity to wear a wig. ${ }^{140}$

The case also illustrates several of Justice Morrow's characteristics. It was a financial loss as his remuneration hardly met his expenses and thus it was another instance of his work as an unpaid litigator. It was also an adventure to take a case to the "foot of the throne" which, at the time, was a dream shared by many litigators. Finally, it illustrates the care and concem he felt for upcoming members of the profession. ${ }^{41}$ His decision to take The Honourable Wm. A. Stevenson, Justice of the Supreme Court of Canada, who

The Sand and Gravel Act, S.A. 1951, c. 77 and The Clay and Marl Act, S.A. 1961, c. 14 have been re-enacted in The Law of Property Act, R.S.A. 1980, c. L-8, ss. 53-54.

Earl F. Wakefield Co. v. Oil City Petroleums (Leduc) Lid., [1960] A.C. 18, [1959] 3 W.L.R. 631, 29 W.W.R. (N.S.) 638 (P.C.), aff'g [1958] S.C.R. 261, rev'g (1957), 22 W.W.R. (N.S.) 267 (Alta. S.C.A.D.). Justice Morrow wrote about this case in "The Last Case" (1978) XVI Alta. L. Rev. 1.

Interview with The Honourable J.H. Laycraft, Chief Justice of Alberta (16 January 1990). Chief Justice Laycraft was junior counsel for J.V.H. Milvain and R.M. MacKimmie, Q.C., who acted for the opposing side in this case.

"Firsts" were a recurring theme throughout Justice Morrow's career. The authors have cited only some examples -- there is a list of approximately seventy or eighty "firsts" in Justice Morrow's personal papers.

Unidentified newspaper article (8 July 1959). In fact, there was an order that the wearing of wigs be dispensed with throughout the court system because of the oppressive heat in London at the time: Letter from The Honourable Wm. A. Stevenson, Justice of the Supreme Court of Canada to Sherrilynn J. Kelly and Jan Alexander Smith (29 June 1990).

Letter from The Honourable Wm. A. Stevenson, Justice of the Supreme Court of Canada to Sherrilynn J. Kelly and Jan Alexander Smith (29 June 1990).

While Justice Morrow gave articling students a great deal of independence, he also tried to involve them as much as possible. They would accompany him on cases, much as his briefcase did. Moreover, for the first few years of their careers, they often assisted as junior counsel: Interview with The Honourable Wm. A. Stevenson, Justice of the Supreme Court of Canada (8 January 1990). 
was then just a beginning lawyer, was motivated not only by the latter's invaluable assistance but with the awareness that few, if any, of that generation of lawyers would ever have such an opportunity.

Justice Morrow was also involved in numerous real property cases. ${ }^{42}$ Kaup and Kaup v. Imperial Oil Limited ${ }^{43}$ is just one example. In that case it was held that The Land Titles Act $^{44}$ modified the common law rule that "no man can convey a better title than he possesses" only insofar as it established special rights for bona fide purchasers for value; the land titles system does not protect a volunteer.

Barleben v. Barleben ${ }^{45}$ in which Justice Morrow appeared as counsel, is a relatively early decision involving the rights of co-habitees. In that case, it was held that when people hold themselves out as husband and wife, although not married, and contribute money and services to the acquisition of property, they should not be treated as strangers but as married persons as nearly as possible.

Justice Morrow also acted in malpractice cases, defamation suits, and virtually every other conceivable type of litigation. His experience as a litigator served him well when he began to go on circuit in the north as a volunteer defence lawyer: ${ }^{46}$ he was exposed to much more criminal law than he had been in the past.

While Justice Morrow did some criminal work in Edmonton, he largely left it to others who specialized in that area. In 1960, he argued the Canadian Bill of Rights before the Supreme Court of Canada for the first time; his argument was unnecessary, however, for the Court to agree with him in quashing his client's conviction for perjury. ${ }^{47} \mathrm{He}$ also acted for an accused in an alleged conspiracy to defraud the government. ${ }^{48}$ At the time, farmers did not pay tax on gas which was accordingly dyed purple so others could not use it. The people involved were accused of falsifying documents so it would appear that gas had been dyed purple -- the gas could, in turn, be sold as regular gas without the tax ever having been paid.

Throughout his years in practice, Justice Morrow appeared before every court in Alberta as well as in British Columbia and the Northwest Territories. He appeared before

42. Meduk v. Soja, [1958] S.C.R. 167; British American Oil Co. Lid. v. Kos (1963), 46 W.W.R. (N.S.) 141 (S.C.C.); Krook v. Yewchuk (1962), 39 W.W.R. (N.S.) 13 (S.C.C.); Credit Foncier Franco-Canadien v. Edmonton Airport Hotel, [1965] S.C.R. 441; Canadian Construction Co. Ltd. v. Beaver (Alberta) Lumber Ltd., [1955] 3 D.L.R. 502 (S.C.C.); Ruptash and Lumsden v. Zawick (1956), 2 D.L.R. (2d) 145 (S.C.C.). (1962), 37 W.W.R. (N.S.) 193 (S.C.C.), aff'g (1961), 35 W.W.R, (N.S.) 433 (Alta. S.C.A.D.), aff'g (1960-61), 33 W.W.R. (N.S.) 117 (Alta S.C.T.D.).

4. R.S.A. 1942, c. 205.

45. (1964), 46 W.W.R. (N.S.) 683 (Alta. S.C.A.D.).

46. The word "volunteer" is appropriate because as defence counsel Justice Morrow only received $\$ 10.00$ per case.

47. Calder v. The Queen, [1960] S.C.R. 892.

48. R. v. Hollman, Hewko and Melnyk, (1962) 37 W.W.R. (N.S.) 337 (Alta. S.C.A.D.). 
the Supreme Court of Canada on 10 leave applications and on 21 appeals. ${ }^{49}$ While one might presume that Justice Morrow was essentially a barrister, he also did considerable work as a solicitor: wills and estates, conveyancing and some corporate-commercial work..$^{\text {so }}$

He was also involved in administrative work such as appeals before the Income Tax Appeal Board and municipal Boards of Assessment Revision. He acted in expropriation matters both for and against the expropriating authorities. His representation of the federal government in expropriating the farm land around Nisku for the Edmonton International Airport was typical. While Justice Morrow would have had a tremendous amount of sympathy for a farmer who was about to lose his land, he persisted, in the face of a gun, in having the farmer evicted when he refused to leave voluntarily after having been given the required notice. ${ }^{51}$

Justice Morrow was fearless in his representation of his clients -- guns or no guns. He was not afraid to take issue with a judge where others might have deferred. Once, when a young associate reported that a judge had refused to sign an Order, Justice Morrow ran to the courthouse to confront the judge and demand that it be signed so that he could get on with the appeal. On another occasion, when his client's petition for divorce was about to be denied because there was no photograph of the respondent, Justice Morrow reminded the bench that divorces were being granted before the advent of photography. ${ }^{52}$ Nevertheless, he was always courteous, respectful, and mindful of his office of barrister and solicitor.

A lawyer is said to have once remarked that Justice Morrow had a code of ethics that an angel would have difficulty living up to. He never hesitated in informing the Court, on discovering a case against him, regardless of his client's protestations. Nor would he enter default judgment or note someone in default without first reminding the opposing lawyer that he had not yet filed his defence. ${ }^{53}$

Justice Morrow was an excellent advocate and adversary. A contemporary recalls that one of Justice Morrow's greatest attributes as a lawyer was that files never sat idly -characteristically, he got on with them. He was also a great raconteur because of his keen sense of the ridiculous, his ability to appreciate situations more quickly than most, and his excellent command of the English language. ${ }^{54}$

so. Justice Morrow actually had a fairly large estate practice; he believed that an estate practice was compatible with a litigation practice. Corporate-commercial work, on the other hand, involves clients who are not always prepared to put up with their lawyer being in court, often for days on end: Letter from The Honourable Wm. A. Stevenson, Justice of the Court of Appeal of Alberta to Sherrilynn J. Kelly and Jan Alexander Smith (29 June 1990). Supra, note 3.

Ibid.

Ibid.

s4. Supra, note 37. 
Justice Morrow acted as commission counsel in a number of inquiries. He developed an expertise in investigations into maladministration. He was appointed assistant commission counsel, and later commission counsel, into the opposition's charges of misconduct by the Social Credit government, which had been made in the last session of the legislature before the 1955 election..$^{5}$ In an inquiry which would lead to the resignation of a mayor, Justice Morrow was first appointed as counsel to a Special Investigating Committee of the Edmonton City Council and later as counsel to the judicial inquiry ordered by Premier Manning as a result of a petition by some 568 individuals. ${ }^{56}$ As a result of the Rand Inquiry into the stock dealings of Ontario's Mr. Justice L.A. Landreville, in which Justice Morrow again acted as counsel, Justice Landreville would ultimately submit his resignation as the Senate, in a rare hearing, was about to begin debate on a motion to unseat him..$^{57}$ His experience as commission counsel would serve him well in later life when, as a judge, he was appointed to head a number of inquiries which were also concerned with the probity of public officials' conduct.

One might wonder how Justice Morrow found time to do anything besides work: ${ }^{58}$ He more often than not worked seven days a week. People have joked that when the lights were on in his downtown office, as they often were at night, the airplanes using the municipal airport had an extra beacon. ${ }^{59}$ Those who practised with Justice Morrow, however, also remember that they sometimes spent a great deal of time chatting with him. $\mathrm{He}$ was a prodigious worker as well as something of a worrier. ${ }^{60}$

Justice Morrow did find time to marry and have a family, which was really his only other interest. His widow, Genevieve, recalls that she was "tired" of him before she even met him; his picture had appeared regularly in recruiting advertisements during the war. Justice Morrow's marriage proposal was probably the only time his skills as an advocate failed him. While Mrs. Morrow ultimately accepted his offer of marriage, it was a somewhat off-the-cuff proposal. He had planned to make a passionate appeal during a scenic drive on New Year's Eve. It did not quite work out that way. Later that night, when Mrs. Morrow was mistakenly taken as his wife, he quipped something like, "How about it?" Over the years, Mrs. Morrow would hear bits and pieces of the proposal which he had intended to make. ${ }^{61}$ Humour was but one aspect of their thirty-three year marriage. They also shared many adventures and challenges. Mrs. Morrow was not only his counsel, but his judge and jury in many of their discussions concerning the law. They had three sons, William, Lee, and Jack, and one daughter, Polly.

ss.

56.

57.

so. One contemporary recalls Justice Morrow saying that "to find a lawyer without a briefcase at the end of his arm was to find a fellow who was sick." If Justice Morrow saw a lawyer leaving for home without his briefcase he would query whether it had been lost: supra, note 37 .

61.

The Macdonald-Mchaffy Commission (1955).

The Porter Commission (1958).

The Rand Commission (1966).

Justice Morrow was also very active in the Edmonton Bar Association. He served as a Bencher of the Law Society of Alberta from 1964 to 1966. Justice Morrow was also the first Canadian director of the American Judicature Society.

Supra, note 7

Supra, note 7. 
Justice Morrow also found time to enter the political arena. In 1947, he was elected to the Edmonton Public School Board for a two-year term as a Candidate of the Citizens' Committee. ${ }^{62}$

In 1965, he made an unsuccessful bid for the Liberal nomination in Edmonton-West. Mrs. Morrow prompted Justice Morrow's decision to enter the political foray since he was forever criticizing the government of the day while they listened to the news. He agreed to let his name stand on the understanding that his nomination would be unopposed, because his schedule would not permit him to campaign vigorously. Unkown to the Morrows, another candidate was actively campaigning in that riding and had been for nearly a year. Having agreed to run, Justice Morrow felt compelled to see it through. ${ }^{63}$ Notwithstanding the many demands of his practice, he hit the campaign circuit discussing and debating the proposed Canada Pension Plan, the new flag, relations with Quebec, and reciprocity, among other issues. Many believe he would have been unhappy as a politician. His penchant for stating the truth as opposed to saying what the electorate wanted to hear - a strategy unknown to some successful politicians - suggests Canada was better served by his appointment to the bench.

It was a hectic and rewarding twenty odd years as Justice Morrow rose to the height of his profession. Nonetheless, Justice Morrow believed that good lawyers had an obligation to accept judgeships.

\section{THE NORTH}

On September 12, 1966, William George Morrow was sworn in as the second Justice of the Territorial Court of the Northwest Territories before B.G. Sivertz, the Commissioner of the Northwest Territories, who, twenty-four years earlier had taught him navigation at H.M.C.S. Kings. While "[r]ight man, right place" was how the Editorial in The Edmonton Journal on September 2, 1966, characterized his appointment, Justice Morrow clearly had misgivings about accepting a judgeship.

The decision to accept the appointment had not been an easy one for Justice Morrow: he had been approached on at least two earlier occasions. He was well aware that the north was remote, harsh, and undeveloped. He also knew that as the only superior court judge he would be isolated. Apart from the financial sacrifice ${ }^{64}$ it would entail, there was also his family to consider. Mrs. Morrow feared the children would lose "all sense of their roots" and had also been known to say "I would rather be married to a lawyer in Edmonton than a judge in the Northwest Territories". ${ }^{65}$ Justice Morrow and his family were comfortable in Edmonton: he had a successful practice, they had a lovely home, a cottage in Jasper, the older children were in the latter years of their primary education, they had many friends and family -- in short, their lives were there. While the family

\footnotetext{
62. The Edmonton Journal (6 November 1947).

63. Supra, note 7.

64. In 1967 , territorial judges received a $\$ 5,000.00$ raise; they would now make $\$ 26,000.00$ per annum: An Act to Amend the Judges Act, S.C. 1967-68, c. 20.

6s. Supra, note 7.
} 
ultimately rallied around his decision to accept the appointment, it was another two years before they made Yellowknife their home; Justice Morrow commuted in the interim. Shortly after he accepted the appointment, an emotional Justice Morrow confided in a former partner, that he had made a mistake in accepting it. ${ }^{66}$ The responsibility of accepting such an appointment, however, overshadowed any self-doubts.

When asked why a successful lawyer would leave his practice to become a judge in the most isolated part of Canada, Justice Morrow was quoted as saying that "he felt he was doing just what his parents had done by coming to Edmonton many years ago. The north is a new country developing, interesting, and challenging. ${ }^{.67}$

At his swearing in, Justice Morrow countered the accolades bestowed on him by saying, "my favourite topic up until now was criticizing judges. Now I must remember to listen, not talk."68 The transition, however, from litigator to judge was not that easy. Shortly after his appointment, he regaled his former partners with how the Crown in one case, over his protestations, had been trying to put words in the mouth of "his guy": his guy was the accused. ${ }^{69}$ As a lawyer who appeared before him on many occasions has said, he sometimes forgot to take the sign with him which had been a gift on his appointment. ${ }^{70}$ The sign read, "keep your mouth shut".

Until the late Mr. Justice John $\mathrm{H}$. Sissons was appointed as the first justice of the Territorial Court of the Northwest Territories, the administration of justice in the north had been carried on in a somewhat antiquated fashion. When the provinces of Alberta and Saskatchewan were created in 1905 , court services were withdrawn from the territories; superior court justices from the provinces and stipendiary magistrates administered justice in the north for some fifty years."

In 1955, pursuant to the Northwest Territories Act, ${ }^{72}$ a complete court system was established by the Government of Canada in the Northwest Territories. The Act provided for a Territorial Court, which later became the Supreme Court, ${ }^{73}$ a Magistrate's Court, and Justice of the Peace courts.

In keeping with the tradition established by Justice Sissons, Justice Morrow continued to take the Court to the people. Both Justice Sissons and Justice Morrow believed that this would assist the Court and the people in becoming more familiar with each other's

Supra, note 3.

News of the North (15 September 1966).

Unidentified newspaper article.

Supra, note 3.

Interview with Mr. G. Brian Purdy, Q.C. (9 November 1989). The sign had been a gift from the late Basil Dean, then publisher of The Edmonton Journal: Letter from The Honourable Wm. A. Stevenson, Justice of the Supreme Court of Canada to Sherrilynn J. Kelly and Jan Alexander Smith (29 June 1990).

Northwest Territories Act, R.S.C. 1906, c. 62.

R.S.C. 1952 , c. 331 , s. $20(1)$.

Territorial Supreme Courts Act, S.C. 1972, c. 17. 
roles, concerns, and limitations. ${ }^{74}$ It allowed them to experience the native way of life, to educate themselves about aboriginal customs and beliefs, and to fashion a more appropriate judicial response than would perhaps have been possible had they remained in Yellowknife.

Administering justice in the north was governed by the enormous distances, severe climatic conditions, the small, scattered population, language, and the then-existing technology. As Justice Morrow was often heard to say, "[w]e go where we can and when we get there, we do what we can, as best we can, with what we got." ${ }^{75}$

The jurisdiction of the Court extends north 2,100 miles from the 60th parallel to the North Pole and 2,800 miles from the Yukon on the west to Labrador on the east. In total the Northwest Territories encompasses 1,300,000 square miles or approximately one-third of Canada's total land mass. The territories consist of a mainland lying west of the Hudson Bay-Foxe Basin and south of the Beaufort Sea, and the Arctic Archipelago which includes numerous islands -- eighteen of which are larger than Canada's smallest province. The diverse topography is characterized by regions of permanently frozen ground, a flat and barren landscape which rises to the highlands and the mountains, extensive valleys shaped by glaciers as well as many lakes and wetlands. Similarly, there are marked differences in climatic conditions throughout the territories which are often unpredictable.

The population of the north corresponded to the geography: the Eskimo occupied the arctic, the Indians the subarctic and the white people were generally found in the settlements. In 1970, the population of the north was barely double that of when Justice Sissons was appointed in 1955. Each group made up roughly one-third of the total population of $32,000 .^{76}$

Although there was a courthouse per se in Yellowknife, during Justice Morrow's years on the bench, court was held in living rooms, a dance hall, school houses, a warehouse, community halls, on the frozen Arctic ocean, on a float plane in the middle of a lake, on the plane in mid-air and even outdoors. Once, when Justice Morrow was still a lawyer, he had to interview his client in the outhouse because it was the only place where they could find any privacy. On another occasion, a jury had to be excused to parked cars while a voir dire was being conducted. ${ }^{77}$

Certain accoutrements accompanied the Court wherever it went. The flag was always flown and two signs always hung. When the Imperial Order of the Daughters of the Empire presented Justice Morrow with the Canadian flag on April 10, 1967, he repeated the same words Justice Sissons had spoken many years earlier when he had accepted a

74. Justice Morrow authored a layman's guide to the law entitled, "Justice in the North", in 1975. It was published both in English and Eskimo Syllabics by the federal government.

75. The Edmonton Journal (3 May 1971).

76. William G. Morrow, "Law and the Thin Veneer of Civilization" (1970) X Alta. L. Rev. 38; John H. Sissons, Judge of the Far North (Toronto: McClelland and Stewart, 1968).

n. William G. Morrow, "Adventures in Administering Justice in the North" (Address to the University of Saskatchewan, Saskatoon, Saskatchewan, 18 November 1971) (unpublished]. 
Canadian ensign: "[w]herever this court sits on circuit this flag will be planted outside."78 The two signs were the Canadian Coat of Arms and a "no smoking" sign in four languages. ${ }^{79}$ What they could take for a library was stored in a suitcase. Justice Morrow also designed a red sash "which he [wore] quite deliberately to impress on the Eskimos that he [was]n't just another government man from the south...." ${ }^{80}$ The comforts of home, however, did not accompany the Court party. They often depended on the hospitality of people in the community where court was being held. Justice Morrow also took a survival kit, which was just what the name implies. And while he was known to take a gun, the description of the "pistol-packing judge" is best left to western novels.

The many languages and dialects in the north were also problematic. For example, "guilty" and "not guilty" cannot be translated with any precision into the Eskimo language and some Indian dialects. ${ }^{81}$ Thus, extra care had to be taken to ensure that an accused understood what was being asked of him when he was requested to plead to the charge. Similarly, "judge" translates as "one who listens" or "boss" in the Eskimo language. When the court was composed of a judge and a jury, Eskimo interpreters would describe it as "a big boss and six small bosses." ${ }^{182}$ The Jury Ordinance ${ }^{83}$ also prevented people from serving as jurors unless they spoke English. Such a prohibition, coupled with the size of some communities, made it much more difficult to hold jury trials.

While Justice Morrow had experienced circuit life as defence counsel, he now had the task of planning and co-ordinating the circuits. In those days the only road into the Northwest Territories was the Mackenzie Highway which terminated at Yellowknife. Aviation was, of necessity, the only way to take the Court to the people.

Although circuits were dictated to some degree by demand, they were extremely dependent upon the ability to travel which was, in turn, governed by the weather, the limitations of navigation, and the short range of early airplanes. The "spring circuit", which included Baker Lake, Cape Dorset, Frobisher Bay, ${ }^{84}$ Baffin Island, and Pond Inlet, was so organized because of the continuous sunlight and good flying conditions at that time of the year. Likewise, during the "summer circuit", the Court would use pontoon equipped airplanes to fly into the central and eastern Arctic because experience had shown that it was the best time of the year to gain access to this area of the territories. ${ }^{85}$

\footnotetext{
78. News of the North (13 April 1967).

79. The Toronto Daily Star (10 April 1969).

80. The Edmonton Journal (5 May 1971). The judiciary in the Northwest Territories still wear the sash today.

81. The Montreal Star (6 February 1975).

82. Time Magazine (6 June 1969).

83. R.O.N.W.T. 1956, c. 55. A recent amendment to the Jury Act, however, provides that native people who speak only their aboriginal language will be allowed to serve as jurors: The Edmonton Journal (8 September 1989).

84. Frobisher Bay has been renamed Iqualuit.

85. Interview with Mr. R.P. Engle (24 January 1990).
} 
In the early days, entire communities would welcome the plane; the sheer novelty of such a sight created an "event". Not only was court held in odd places, it was also held at odd times because of the weather conditions, the variability in daylight hours, the demands of the particular circuit, and the available facilities. Counsel often met with their clients or witnesses, sometimes for the first time, shortly after arrival, and court would be held a few hours later. Flexibility was, needless to say, a virtue.

Advances in technology saw the Court party move from single engine to twin engine bush planes and eventually to a DC-3. The short range of the single engine aircraft meant carrying fuel in the cargo compartment -- three or four ten-gallon kegs. While there was little risk of an explosion when the kegs were full and properly sealed, the risk may well have been greater had a fire broken out during a crashlanding: the kegs would, in effect, have been an auxiliary fuel tank. The DC-3 became the regular "Court" airplane because it had twin engines, could fly at higher altitudes, and had a longer range, which made it possible to "overfly" rather than "commit" to bad weather. The DC-3, however, had its limitations too; there had to be a landing strip of some sort. While it could be equipped with skis in the winter to land on ice strips, the Court party had to revert to float planes in the summer to get to the communities which did not have landing strips. ${ }^{86}$

In 1971, the opportunity to test a Learjet in the north presented itself. To be useful, the airplane, among other things, had to be able to withstand the extreme temperatures. On the second day of the circuit, the Learjet was kept outside overnight, over the protestations of the airplane representatives, who wanted to fly it back to Yellowknife where it could be housed in a hangar. The next day the Learjet failed the test to the undoubted horror of its passengers. One engine failed approximately twenty minutes after leaving Resolute Bay and an hour and a half away from their destination at Cambridge Bay. Although an airplane can fly on only one engine, if the cause of the failure was attributable to the cold, which was at that point unknown, the second engine was likewise at risk of failing. As an experienced aviator, who was on the flight, recalls, "if an emergency landing ... had to be elected ... survival was very unlikely because it was a high-performance airplane and would be landing at 140 knots and would likely completely self-destruct on the rough ice conditions. ${ }^{187}$

A member of the crew tried to allay the fears of the passengers when he observed that they had all had experiences with small planes and indeed, even single engine Otters, whose engines had failed and they had survived. One of the passengers looked up morosely and said, "you're forgetting something, you can glide an Otter." 88

The recollections of those on board echo an understandable fear. According to the court reporter on that circuit:

86. Ibid.

87. Ibid.

88. Letter from The Honourable Wm. A. Stevenson, Justice of the Court of Appeal of Alberta to Sherrilynn J. Kelly and Jan Alexander Smith (29 June 1990). 
... we heard a bang ... and we dropped rather quickly.... Nobody said a word and the Judge was sitting there, totally unperturbed, and he says, 'well they asked us to see how this aircraft would act in the Arctic. Now we know how it acts on one engine. Pretty soon we might find out how it acts on no engines. ${ }^{89}$

The north was not ready for the Learjet; or perhaps, more accurately, the Learjet was not ready for the north. It required a 5,000 to 6,000 foot airstrip to land on, which there were few of in those days. Nor could it be equipped with skis or pontoons which further limited the areas it could travel to. Technology was too advanced for what was then needed.

Ingenuity was necessary for survival in the north because of the long distances between communities, the sudden changes in the weather, and even uncharted areas. On one occasion, the court party flew on the "spit of the pilot", in frigid temperatures for some twenty-five hundred miles; it was the only way to keep the air in an otherwise flat tire. ${ }^{90}$

While Justice Morrow was not an aviator, he was a keen navigator owing to his days in the navy. He had his own navigation charts and often spent his time inflight charting the course along with the pilot. He was also very much a part of the crew. On one occasion, the pilot was having problems getting the plane turned around because of an overflow -- water below the surface ice which made it difficult to operate on skis because it impeded the plane's ability to gain momentum. Planes in those days had lanyards attached to the tails to turn them around because there was no nose-wheel or tail-wheel steering. While helping to swing the tail around, Justice Morrow got tangled in the lanyard as the airplane started to accelerate; he thought he might be airborne for a moment. ${ }^{\text {91 }}$

Justice Morrow described his adventures in the north as "fun times". Another example is when Justice Morrow planned the "North of 60" project with Mr. R.P. Engle, who was the pilot on many of the court circuits. They, along with Mrs. Morrow, were going to fly around the world north of the sixtieth parallel. Unfortunately, the Soviet Union quashed their plans by refusing permission to fly over it. ${ }^{22}$

The Court party itself consisted of the Judge, defence counsel, the Crown, a court reporter, and a clerk. The accused or litigants, witnesses, probation officers, and Royal Canadian Mounted Police also accompanied the court party on occasion. The Court party developed a strong sense of camaraderie given the many hours they spent together. They were dedicated professionals. While vigilant in safeguarding pending cases, they often discussed past cases -- articulating special problems, irritations or issues of particular significance. Many believe they shared a special understanding of each other's roles and certainly a better appreciation of how tenuous the success of the circuit system could be: each of their roles was crucial to seeing that justice was served. 
Justice Morrow's enormous capacity for work and his unrivalled ability to keep up a demanding pace were well known. Some felt that he occasionally overlooked the needs of the Court party, particularly in terms of eating and sleeping. The days were long and the circuits arduous. The pace he set could be exacting. Yet, as many of the people who travelled those circuits have said, you have to like what you are doing if you are going to keep doing it.

\section{ADMINISTERING JUSTICE IN THE NORTH}

Justice Morrow's years in the north, both as a lawyer and as a judge, must be assessed within the purview of the times.

As an ardent Canadian, Justice Morrow considered the north our "last frontier". Although often described as "problems" in the administration of justice in the north, he frequently characterized the difficulties he encountered as being the "realities" of the north. He felt that many misunderstood and ignored the north; he took it upon himself to explain, educate, justify, and enlighten. Justice Morrow believed that the problems which were peculiar to administering justice in the north were threefold: constitutional, economic, and cultural..$^{93}$

\section{A. CONSTITUTIONAL}

The federal government has often been condemned for its colonial attitude toward the Northwest Territories. In 1967, the year after Justice Morrow was appointed to the bench, the territorial government was moved to the new territorial capital of Yellowknife. The territories had been governed from Ottawa since 1905 by an appointed commissioner and council. In 1951, members of the council began to be elected, and by 1975, it was an entirely elected body. However, the commissioner was still appointed by the federal government and acted under the instructions of the Minister of Indian Affairs and Northern Development. It was not until 1970 that the territorial government assumed responsibility for most aspects of administering justice in the north.

Consequently, the distinction between legislative, executive, and judicial powers was less marked than in other parts of the country. Justice Morrow was in very close contact with both the agencies of government and the people it served. Some government people in those days perceived the judge as just another civil servant "who should be kept in his place", ${ }^{94}$ and yet he himself enjoyed a certain measure of independence, much to their annoyance, which they themselves did not. While a strategy for self-government remains elusive, Justice Morrow, during his time in the north, strove to keep the judiciary separate and independent.

\section{B. ECONOMIC}

William G. Morrow, "Current Problems in the Administration of Law in the Northwest Territories" (Address to the University of Westem Ontario, London, Ontario, 4 November 1974) [unpublished].

94. 
The vast resources in the north present many economic issues which in turn raise social, political, and environmental concerns. The energy crisis of the seventies sparked a sudden interest in the north, and consequently increased expansion into hitherto untouched areas.

R. v. Kenaston Drilling Arctic Ltd. ${ }^{95}$ is an example of Justice Morrow's view that a special approach was required when dealing with the rapid development in the north; where outsiders, with little-to-no appreciation of its vulnerabilities, transgressed the law.

Kenaston was charged with unlawfully conducting a land use operation in a land management zone without a permit for which the maximum penalty was a $\$ 5000$ fine. The company had moved a piece of heavy equipment, with a seismic drill mounted on it, across the land instead of using the ice road. Kenaston believed the spring weather had softened the ice to the point where the road might have been unsafe. Kenaston entered a guilty plea and was fined $\$ 100$.

In hearing the Crown's appeal on sentence, Justice Morrow said:

It can be observed that the same weather conditions which would soften the ice under the ice road would also tend to soften the surface area of the tundra and it is for this reason that the permit in question is required and was probably not extended another period... . 96

\begin{abstract}
I would be remiss as a Judge in this territory if I did not take notice of the need and purpose of the present legislation, to protect the 'control and use of the surface of the land', a land which although tundra in nature and frozen over for many months each year is none the less a delicate land, easily damaged and perhaps once damaged impossible to repair. This is without any mention of the possible use that our original inhabitants, in this case Eskimos, may still be making of it and how their way of life may still be dependent on its being preserved in its natural state.
\end{abstract}

Justice Morrow, in imposing a fine of $\$ 2000$, without any finding of damage, felt the Court should stress deterrence rather than allow the potential economic rewards to persuade some to undertake a calculated risk. He also intimated that notwithstanding the significant increase in the amount of the fine, the company was still being treated more leniently than other offenders might expect in the future. ${ }^{98}$ Anticipating what the future might hold, Justice Morrow once asked rhetorically, "[w]hat's going to happen when the exploration is over?"199

\title{
C. CULTURAL
}

The clash between different cultures manifested yet another dilemma. It is in this respect that both Justice Morrow and his predecessor, Justice Sissons, made their greatest and most lasting impact in interpreting the law amid the realities of the north and also

95. (1973), 12 C.C.C. (2d) 383.

\%. Ibid. at 384-5.

97. Ibid. at 386.

98. The Edmonton Journal (10 May 1971).

99. William G. Morrow, Address (Grant MacEwan Community College, Edmonton, Alberta) as quoted in The Edmonton Journal (7 December 1972). 
received their severest criticisms and loudest accolades. Justice Morrow had a clear perception of his pioneering role in the north: ${ }^{100}$

\begin{abstract}
All down the line I have the feeling, as did my illustrious predecessor, that as native people struggle to save some of their culture and at the same time endeavour to become part of the so-called southern culture, the Court represents the buffer, offers one of the few available means, to prevent a too rapid erosion of the old way of life. The Court in my opinion is forced to at least try to soften the blow. The effort may not always succeed, the decisions may not at times be popular, but if "justice" is to be more than an idle term then it is the Court's function and duty, my responsibility, to as much as possible bend the law if necessary to see justice done.
\end{abstract}

Justice Morrow saw the cases before him as a judge, and those he participated in as counsel, as reflecting the transformation from a "furtrading [sic] way of life to the era of oil wells and pipelines."101 The cultural dilemma is most aptly illustrated in four particular areas of the law: marriage and adoption, hunting and fishing rights, land claims, and discriminatory laws.

\title{
1. Marriage and Adoption
}

Justice Morrow, like Justice Sissons was keenly aware that the family unit in the north was historically as much an economic unit as a social institution.

The validity of Eskimo custom marriages came squarely before Justice Sissons' court in Re Noah Estate, ${ }^{102}$ when the Court had to decide who the deceased's next-of-kin were: his widow and child or his siblings. Although Eskimo customary marriages were "conducted without the benefit of a preacher, church or ceremony", ${ }^{103}$ there were certain practices and social amenities which served to cement and publicize the marriage, albeit not those which were required by the Marriage Ordinance. ${ }^{104}$ Justice Sissons took exception to the government's argument that such marriages were not marriages as understood by western Christendom but simply a form of concubinage. Justice Morrow, who acted for the widow and child, played an integral role in the result of this case. Marriages in accordance with Eskimo custom were held to be "as legal and binding as any in Canada". ${ }^{105}$

\section{As Justice Morrow has said:106}

...it does not take too much imagination to see how a rigid and literal interpretation of our Criminal Code or other of the white-man's laws would not only create confusion in the minds of these people but cause real injustice.

Cases involving adoptions in accordance with Eskimo and Indian customs augmented Justice Morrow's beliefs. Giving away children, at least insofar as the Eskimo culture

William G. Morrow, "North/South Cultural Difference - Role of Court" (Address to Queen's University, Kingston, Ontario, 15 February 1974) [unpublished].

Ibid.

(1961), 36 W.W.R. (N.S.) 577.

The Edmonton Journal (7 May 1971).

R.O.N.W.T, 1956, c. 14.

Supra, note 103.

William G. Morrow, "Northern Judge Looks at Law and Native Custom" (Address to University of Calgary, Calgary, Alberta, 28 January 1970) [unpublished]. 
was concerned, was borne of necessity. Historically, Eskimos practised infanticide, particularly in the case of daughters. This practice, however, was discouraged by white people as the two cultures began to meet. Moreover, the advent of welfare and child allowances decreased the need to do so. Illness, having too many children who were close in age or twins, empathy for childless couples or an aging and lonely grandmother, however, continued to motivate the giving away of children. In what Justice Morrow described as "perhaps the saddest case" of the more than two hundred which he had then heard, a mother gave her child away because "all of her children had died and she wanted this one to live". ${ }^{107}$ Presumably, similar reasons motivated the same practice among Indians.

The legal validity of Eskimo custom adoptions was first recognized by Justice Sissons in Re Katie's Adoption Petition. ${ }^{108}$ In extending the practice to custom adoptions by Indians, in Re Beaulieu's Petition, ${ }^{109}$ Justice Morrow recognized, as Justice Sissons had before him, "... that the Indians ... have from time immemorial practised and recognized custom adoption and that 'these people should not be forced to abandon it and it should be recognized by the court. '"110 In deciding in Re Deborah E4-789 that the legislation in the Northwest Territories had not abrogated custom adoptions, Justice Morrow was compelled to find against the natural parents who had given their youngest daughter away some twelve years earlier."

Newspaper accounts of the day suggest $R e$ Deborah was a significant decision in native rights. ${ }^{112}$ However, the validity of custom adoptions was already firmly established. In interpreting the history of the legislation, Justice Morrow said, "... I cannot find any of the language contained therein that is repugnant to or could either directly or by implication be taken as being intended to override or repeal the native customs in respect of adoption." 113

\section{Hunting and Fishing Rights}

An anecdote which illustrates the encroachment on native rights was reiterated in $R$. v. Sikyea. ${ }^{114}$ A government official was explaining to an Indian chief that he could not shoot ducks in the spring because of the Migratory Birds Convention when: ${ }^{115}$

The chief asked what was this convention and was told it was a treaty between Canada and the United States. He then queried, 'Did the Indians sign the treaty?' The reply was, 'No.' 'Then[,]' the chief declared, 'We shoot the ducks.'

Re Deborah E4-789, [1972] 3 W.W.R. 194 at 198, aff'd [1972] 5 W.W.R. 203.

(1961), 38 W.W.R. (N.S.) 100.

(1969), 67 W.W.R. 669.

lbid. at 670.

Supra, note 107.

i.e. The Edmonton Journal (24 February 1972).

Supra, note 107 at 204.

(1962-63), 40 W.W.R. (N.S.) 494.

Ibid. at 496. 
On May 7, 1962, Michael Sikyea shot a duck for food. He was subsequently convicted of killing a migratory bird out of season under the Migratory Birds Convention Act ${ }^{116}$ and fined $\$ 10.00$ plus costs and had his rifle seized. ${ }^{117}$ On appeal, Justice Sissons overturned the conviction: ${ }^{118}$ the Act had no application to Indians hunting for food and thus did not curtail their hunting rights.

The Court of Appeal of the Northwest Territories, however, thought otherwise. ${ }^{119}$ It is clear the Court of Appeal was also troubled by this case. Johnson, J.A., speaking for a unanimous court, went to some length to explain:

The rights of Indians to hunt and fish for food on unoccupied Crown lands has always been recognized in Canada - in the early days as an incident of their 'ownership' of the land, and later by the treaties by which the Indians gave up their ownership rights in these lands... ${ }_{120}$

It is, I think, clear that the rights given to the Indians by their treaties as they apply to migratory birds have been taken away by the $A c t$ and its Regulations. How are we to explain this apparent breach of faith on the part of the Government... . 121

In allowing the appeal and affirming the conviction imposed by the Magistrate, Johnson, J.A. concluded: ${ }^{122}$

I regret that I cannot share the satisfaction that was expressed by McGillivray, J.A. in $R$. v. Wesley 58 C.C.C. at 285, [1932] 4 D.L.R. at p. 790, 26 A.L.R. at p. 451, when he was writing his judgment dismissing the appeal in that case:

It is satisfactory to be able to come to this conclusion and not to have to decide that the 'Queen's promises' have not been fulfilled. It is satisfactory to think that legislators have not so enacted but that the Indians may still be 'convinced of our justice and determined resolution to remove all reasonable cause of discontent."

The duck, throughout the litigation, had spent most of its time in a freezer. When the Crown requested all exhibits for the appeal pending before the Supreme Court of Canada, the duck was wrapped and sent by air express to Justice Morrow who in turn had it stuffed for its trip to Ottawa. This was to be the first time any stuffed bird or animal was to make an appearance in the Supreme Court. ${ }^{123}$ Justice Morrow, together with Betty Hagel, had taken Mr. Sikyea's case, at their own expense, on appeal.

Hall, J., speaking for the Supreme Court of Canada, ${ }^{124}$ agreed with the decision of Johnson, J.A.: ${ }^{125}$

He has dealt with the important issues fully and correctly in their historical settings, and there is nothing which I can usefully add to what has been written.

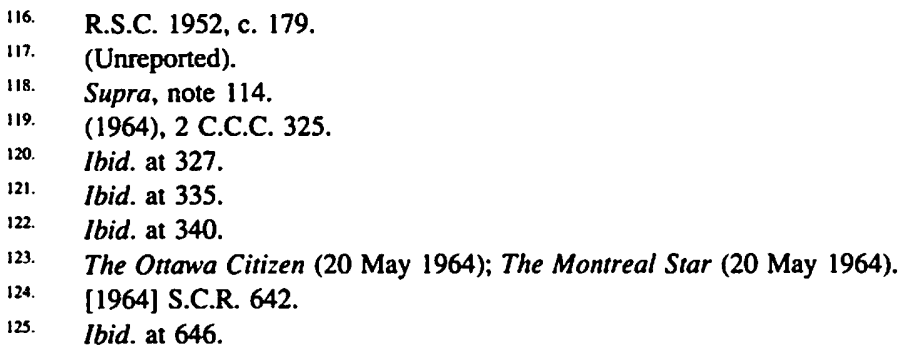


Justice Morrow viewed this case as a clash of cultures, and believed the result was a grave injustice, a view which was shared by many. It was to be the first of many inroads into native hunting and fishing rights.

As his final rejoinder, Justice Morrow, acting on behalf of Mr. Sikyea and several other Indians, petitioned the Exchequer Court of Canada on the basis of the 1921 treaty in which the Indians had purportedly given up their rights to the Northwest Territories in exchange for the right to pursue their usual vocations of hunting, trapping, and fishing. The treaty also provided for a number of other promises which the government had failed to honour. The essence of the petition was either return the land ceded or deliver the promised benefits. ${ }^{126}$

In 1964, Sigeareak E1-53 ${ }^{127}$ was acquitted of killing and abandoning game which was fit for human consumption. The Magistrate, in deciding the case, held that on the basis of $R$. v. Kogogolak ${ }^{128}$ and $R$. v. Kallooar ${ }^{129}$ that the Game Ordinance ${ }^{130}$ did not apply to Eskimos. Justice Sissons, who heard the appeal, by way of stated case, adhered to the views expressed by him in these two earlier decisions. ${ }^{131}$

The Court of Appeal of the Northwest Territories, in reversing Justice Sissons, held that the act of abandonment was not part of hunting for food. It was not a hunting restriction, but a law aimed at the preservation of game. ${ }^{132}$

Justice Sissons, in holding that the Game Ordinance did not apply to Eskimos, had relied on the Royal Proclamation of 1763. In a unanimous decision of the Supreme Court of Canada, ${ }^{133}$ Hall, J., relying on the decision in Sikyea, said the proclamation excluded lands that were once held by the Hudson's Bay Co. which was where the offence occurred. In so deciding, the Court expressly said that Justice Sissons' decisions in Kogogolak and Kallooar "[were] not good law and must be taken as having been overruled." ${ }^{134}$ Moreover, Parliament had clearly granted to the territorial council the powers to enact such legislation as the Game Ordinance.

Another inroad had been made in native hunting rights: Justice Morrow, as defence counsel, and Justice Sissons had again been thwarted in their attempt to protect the native way of life.

In $R$. v. Smith, ${ }^{135}$ Justice Morrow, sitting as a member of the Court of Appeal of the Yukon Territory, heard an appeal from a conviction for unlawfully hunting game: an

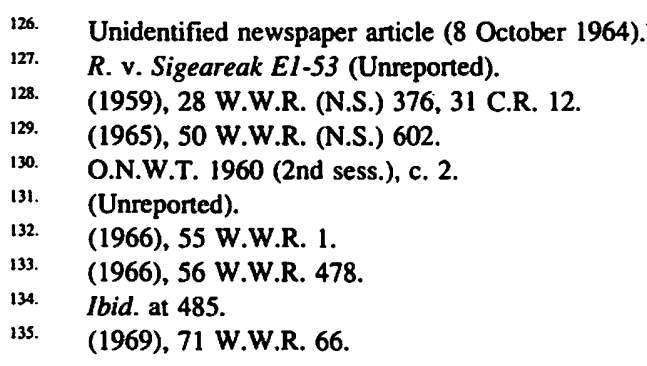


Indian had shot a moose for food within a game sanctuary. While the Game Ordinance $^{136}$ expressly provided that "no person shall hunt game within a game sanctuary", such a complete prohibition had to be read in light of the Yukon Act which contained an exception: ${ }^{137}$

nothing ... shall be construed as authorizing the Commissioner in Council to make Ordinances restricting or prohibiting Indians or Eskimos from hunting for food, on unoccupied Crown lands, game other than game declared by the Governor in Council to be game in danger of being extinct.

There was no evidence of such a declaration with respect to moose. Moreover, unoccupied land did not become occupied by the Commissioner simply designating the land to be a sanctuary. Justice Morrow therefore held that the relevant section of the Game Ordinance was ultra vires.

One might surmise that Justice Morrow felt some measure of satisfaction in adjudicating this decision in light of his experience in Sikyea and Sigeareak. In the latter case, the Northwest Territories Act ${ }^{138}$ contained the identical exception. Justice Morrow, however, was unable to invoke that exception in his defence of Sigeareak; the Governor in Council had declared that barren-ground caribou were extinct. The Supreme Court of Canada took the position that nothing turned on the fact that the declaration was not referred to in the original proceedings. Moreover, while Justice Morrow argued that there was no evidence the caribou in question were barren-ground caribou, the Court said it could take judicial notice of the fact that they were because that was the only kind of caribou known to inhabit the far north which was where the offence had occurred.

Justice Morrow regretted having to find Tootalik E4-321 ${ }^{139}$ guilty of a game offence: unlawfully hunting a female polar bear with young. While he observed the lack of clarity in a phrase such as "without young" in the Ordinance, Justice Morrow was satisfied the accused knew the bears were not to be shot.

The defence, however, also argued that the Court had no jurisdiction. The offence had occurred on the sea-ice offshore from Pasley Bay which is approximately 600 miles north of Churchill, Manitoba. In an extensive judgment, Justice Morrow concluded that the courts in the Northwest Territories had jurisdiction with respect to offences committed not only in the areas of the land comprised in the definition of "territories" in section 2(i) of the Northwest Territories Act, but also in the areas of the sea and sea-ice extending from the land. Thus, the section had to be interpreted as including the sea and sea-ice in all of that part of Canada north of the sixtieth parallel excluding the portions thereof which were part of the Yukon Territory and the Provinces of Quebec and Newfoundland.

The defence had also argued that even if the offence had occurred in Canada, the Game Ordinance was inapplicable because the territorial council had no legislative authority over

\footnotetext{
136. R.O.Y.T. 1958, c. 50, s. 74(2).

137. S.C. $1952-53$, c. 53 , s. 17 , as am. S.C. 1960 , c. 24 , s. 4.

138. R.S.C. 1952 , c. 331 , s. 14 , as am. S.C. 1960 , c. 20 , s. 1 .

139. (1970), 71 W.W.R. 435.
} 
the sea or sea-ice. The point became moot in light of the definition Justice Morrow ascribed to "territories" in the Northwest Territories Act.

The Crown and the defence made a conscious decision not to argue the jurisdictional issue on appeal because they wanted to avoid an adverse decision being made which could haunt Canada in future challenges to her sovereignty. ${ }^{140}$ Justice H.C.B. Maddison, of the Territorial Court of the Yukon Territory, decided the appeal since Justice Morrow had heard the case as a Magistrate. He allowed the appeal because there was a reasonable doubt as to whether the cubs were of an age at which they could not survive without their mother. ${ }^{141}$ Justice Morrow's decision on Canada's international boundaries stands today.

\section{Land Claims}

The emerging contest between native rights and the government was further reflected in Re Paulette, ${ }^{142}$ a complex myriad of legal decisions compounded by, in Justice Morrow's view, an unparalleled attack on the independence of his Court.

In 1973, the Indian Brotherhood of the Northwest Territories attempted to caveat 400,000 square miles of land in the westerly part of the territory. The Registrar refused to register the caveat and referred the question of the legal validity of the Indians' interest to the Court. Justice Morrow adjourned the matter to allow time for the Crown to prepare. To afford some protection to the caveators, in light of the adjournment, he prohibited any dealings with the land in question. Affected parties were, however, at liberty to apply for an exemption and if successful, they would be required to post some sort of security.

When the hearing resumed, the federal Crown advanced two arguments: the Supreme Court of the Northwest Territories had no jurisdiction to hear the case and a caveat cannot be filed on unpatented land. Justice Morrow reserved judgment and directed that an inquiry, as outlined in the reference, be conducted.

The federal government, however, was intent on seeing that Justice Morrow did not hear the case; it instructed the Department of Justice to seek a writ of prohibition. The Federal Court of Canada, Trial Division, convened in Yellowknife four days before the inquiry was to begin, to hear the application. In what might be described as an offensive play, Justice Morrow released an interim judgment in which he held that he did have jurisdiction, albeit a limited jurisdiction, to proceed with the matter. In the end result, Collier, J., dismissed the application and noted that Justice Morrow had "properly and accurately stated" his functions. ${ }^{143}$

Interview with Judge 0.J.T. Troy (18 November 1989); Interview with The Honourable M.M. de Weerdt, Justice of the Supreme Court of the Northwest Territories (2 November 1989).

R. v. Tootalik E4-321 (1970), 74 W.W.R. 740.

[1973] 6 W.W.R. 97 (N.W.T.S.C.), rev'd [1976] 2 W.W.R. 193 (N.W.T.C.A.), aff'd [1977] 1 W.W.R. 321 (S.C.C.).

A.G. Canada v. Morrow, J., [1973] 6 W.W.R. 150 at 155. 
When the inquiry began, counsel for the federal government advised the Court, "[m]y instructions are that I be excused from any further proceedings at this time." ${ }^{144}$ While the federal government chose to "boycott" the inquiry, Justice Morrow nonetheless appointed a Yellowknife lawyer to represent it.

The inquiry was conducted in fifteen communities over the course of the summer. More than thirty witnesses were heard, including individuals who were involved with the actual making of the treaties, anthropologists, and historians. When the inquiry concluded with over one thousand pages of testimony, Justice Morrow was reported to have said, "[i]t was an interesting case" as he left to prepare his judgment. ${ }^{145}$

There was the recurrent theme throughout the testimony that "[a]s long as the sun shines and the rivers run, the Indian way of life will not change."146 The evidence suggested that the Indians thought they were signing peace treaties; not giving up their land. Instead of deciding on the validity of the two treaties in question, Justice Morrow held that there was "sufficient doubt" that their aboriginal title had been extinguished. He further found that an interest in land on the basis of aboriginal rights could be protected by a caveat, and such a caveat could be filed against unpatented land.

Motivated by a sense of faimess and an awareness of the impact such a caveat would have, Justice Morrow stayed the filing of the caveat until the federal government had had the opportunity to exhaust all appeals. He did, however, instruct the Registrar to maintain a record of all dealings with the land in question so that damage, if any, could be assessed, should the caveat ultimately be upheld.

The Indian Brotherhood, in pursuing the litigation, was undoubtedly motivated by the opportunity to gain an advantage in settlement negotiations with the federal government. The judgment was not served to avoid the necessity of an appeal. The caveators apparently hoped that the matter could be settled without further litigation. While the government committed itself to settlement efforts, Justice Morrow's decision was appealed. Both the Court of Appeal of the Northwest Territories and the Supreme Court of Canada decided the case on the narrower and more technical issue: a caveat could not be filed against unpatented lands. ${ }^{147}$

\section{Discriminatory Laws}

14. The Edmonton Journal (10 July 1973).

145. The Yellowknifer (5 September 1973).

146. i.e. Time Magazine (17 September 1973); The Los Angeles Times (4 November 1973).

147. The Indians in northem Alberta also attempted to caveat approximately 25,000 square miles of land in Alberta, including the Athabasca oil sands, on the basis of aboriginal rights. It likewise resulted in the Land Titles Registrar referring the matter to the courts. The matter was adjoumed, however, pending the Supreme Court of Canada's decision in Re Paulette. In its decision, the Supreme Court noted that it was possible to file a caveat on unpatented lands in Alberta and Saskatchewan because the legislation was worded differently. The response, in Alberta, was to enact legislation to disallow filing caveats retroactively against unpatented lands: The Land Titles Amendment Act, 1977, S.A. 1977, c. 27. The govemment was reported as saying that they were only tidying up the legislation: The Calgary Albertan (19 March 1977). 
In a case which many people believe to be Justice Morrow's most significant contribution, he successfully applied the Canadian Bill of Rights ${ }^{148}$ to render a section of federal legislation inoperative for the first and what would be the only time in which a lower court's decision, in so doing, was upheld by the Supreme Court of Canada. The case was also an example of Justice Morrow's innovation in applying the law. ${ }^{149}$

$R$. v. Drybones ${ }^{150}$ involved an appeal from a conviction of being unlawfully intoxicated off a reserve, which was contrary to section 94(b) of the Indian Act. ${ }^{151}$ The accused had initially pleaded guilty to the offence and was fined $\$ 10.00$ and costs or three days in default. As Justice Morrow explained in his judgment: ${ }^{152}$

\begin{abstract}
When it became clear that the appellant did not understand English and that therefore there was some serious doubt as to whether he fully appreciated his plea in the lower Court, he was allowed to withdraw his original plea and the appeal proceeded as a trial de novo with a plea of 'not guilty. 'The Canadian Bill of Rights was allowed to become a ground of appeal.
\end{abstract}

Few who participated in the case foresaw a trip to the Supreme Court of Canada, or its lasting impact. Mr. G. Brian Purdy, Q.C., acting as defence counsel on the appeal, describes how it all came about:

Sissons had given a judgment during his time that said since there were no reserves in the Northwest Territories you couldn't be found to be intoxicated off the reserve. Morrow was standing at the clerk's counter one day in the courthouse when I came up ... and the clerk ... said to him, you know here they've convicted this guy for drinking off the reserve and I thought that Sissons said you couldn't do that.' Morrow looked at it and he said, 'no you can't' and turned to me, I was ... right beside him and said 'will you take this appeal if I appoint you?' ' Well, I was just starting out and I needed all the business I could get so I said, 'sure. '... [Drybones wanted to appeal.] The original appeal papers are just the "off the reserve" issue because I looked up a case in the British Columbia Court of Appeal, Gonzales, ... which was dead on point against me. ... Later I filed a supplementary Notice of Appeal adding the Bill of Rights argument, after I decided the reasoning in Gonzales was wrong. ${ }^{153}$

Justice Morrow distinguished Justice Sissons' earlier decision in $R$. v. Modeste, ${ }^{154}$ where he had treated the "off the reserve" issue as a question of fact. Justice Morrow, in holding that it was a question of law, said: ${ }^{155}$

Is one to say that an Indian who has always lived in the Northwest Territories where there have never been reserves is to be treated differently in the application of a section such as sec. 94 than an Indian from an Alberta reserve who happens to be in the Northwest Territories on a visit - and obviously off a reserve?

Justice Morrow's ruling that "off the reserve" was not an essential element of the offence was overturned both by the Court of Appeal and the Supreme Court of Canada.

S.C. 1960 , c. 44.

The authors invited people to speculate on what Justice Morrow's view of the Charter of Rights and Freedoms would have been. The responses were almost equally divided. Some people believe he would have embraced it. Others feel he would have perceived it as being unnecessary but nonetheless applied it.

(1967), 60 W.W.R. 321 aff'd, (1967), 61 W.W.R. 370 (N.W.T. C.A.), aff'd (1970), 71 W.W.R. 161

(S.C.C.).

R.S.C. 1952 , c. 149.

(1967), 60 W.W.R. 321 at 322.

Supra, note 70.

(1960), 31 W.W.R. (N.S.) 84, 33 C.R. 39, 127 C.C.C. 197.

Supra, note 152 at 327. 
Nonetheless, many people believe that it was illogical that someone could be convicted when there was no reserve to be off of. It was the Bill of Rights argument which prevailed in both higher Courts.

Under the Indian Act, there was a minimum fine of $\$ 10.00$ and a maximum penalty of three months in jail for a conviction of being drunk off of a reserve. Conversely, under the Liquor Ordinance ${ }^{156}$ a person convicted of intoxication in a public place was only liable to a maximum penalty of thirty days in jail - there was no minimum penalty.

Under the Indian Act an Indian could be convicted for being intoxicated in his own home, if it was off a reserve, whereas a non-Indian was only guilty of an offence when he was intoxicated in a public place. Under section $1(b)$ of the Bill of Rights, discriminatory legislation was clearly not prohibited but it would be rendered inoperative where it pertained to "race, national origin, colour, religion or sex" without express words that it operated notwithstanding the Act.

The British Columbia Court of Appeal had earlier decided that there was no discrimination effected by the application of the Indian Act in conjunction with the Bill of Rights. ${ }^{157}$

The Court of Appeal of the Northwest Territories upheld Justice Morrow's decision in Drybones. Johnson, J.A., disagreed with the reasoning which had been employed by the British Columbia Court of Appeal: "[h]e [Tysoe, J.A.] also seems to say that sec. 1(b) permits legislation that discriminates against race so long as all persons within the race that is discriminated against are treated in the same way." 158 Justice Johnson discounted that such could be the purpose of the Bill of Rights because it would restrict its application to equality before the courts, something which "has always been jealously guarded by the courts." 159 The Court also confirmed Justice Morrow's test for discrimination: it is the effect of the legislation and not its purpose.

The Supreme Court of Canada similarly upheld Justice Morrow's decision. Cartwright, C.J., dissented, saying he believed it was not Parliament's intention to give the Court the power to declare validly enacted legislation inoperative and any such intention must be express. The majority, however, dismissed the appeal: ${ }^{160}$

... without attempting any exhaustive definition of 'equality before the law' I think sec. 1 (b) means at least that no individual or group of individuals is to be treated more harshly than another at law, and I am therefore of [the] opinion that an individual is denied equality before the law if it is made an offence punishable at law, on account of his race, for him to do something which his fellow Canadians are free to do without having committed any offence or having been mad[e] subject to any penalty. 
While Justice Morrow, like Justice Sissons before him, may have lost some of the battles, they perhaps won the war. Although their decisions were overturned and legislation was often enacted which abrogated native rights, they helped to bring to the forefront many of the social, political, and economic issues which surround the development of Canada's last frontier.

\title{
D. PHILOSOPHY
}

Justice Morrow's court has been characterized as an activist court because he engaged in a more visible role as "judge as law-maker" than many normally perceive as the traditional mandate of a judge. Justice Morrow was indeed sensitive to this fact: he was fully cognizant that "judges are expected to construe the law, to interpret it, and to apply it, according to the edict of the legislature" and that injustice and hardship must be corrected through amendments to the law. He also believed, however, that within a limited sphere judges should assume the role of law-makers, ${ }^{161}$ as evidenced in the marriage and adoption cases.

Another example is $R$. v. Lockhart ${ }^{162}$ where the Crown objected to the appeal being heard because the proper procedures had not been followed. The Crown, however, was well aware of the fact that $\mathrm{Mr}$. Lockhart intended to appeal his conviction. In hearing the appeal, Justice Morrow said: ${ }^{163}$

\begin{abstract}
Although I realize I am required to apply the law as part of my duty as the sole superior court judge in my territory, I believe also I have a higher duty, namely, to, as much as possible[,] see justice done. I refuse to allow the right hand of the Government, the prosecution, to take advantage of the mistake and error, albeit well-meaning, of the left hand of the same Government. Accordingly, I am going to allow the appeal to proceed and ignore the formal objections of the Crown. Much as I revere the law, and regret having been put in this position, it will have to be a higher court than mine that will have the unpleasant duty to interpret the law in a manner which will deny justice to our native people.
\end{abstract}

Justice Morrow's refusal to disallow Mr. Lockhart's appeal stemmed from the circumstances of the case which were not unique. There were few defence lawyers in the north. ${ }^{164}$ The isolation occasioned both by language and geographical barriers meant many native people were unfamiliar with the law, particularly procedural requirements.

The Right Honourable Pierre Elliot Trudeau, then Minister of Justice, obviously agreed with Justice Morrow. At a press conference in Yellowknife, a few days after the Lockhart appeal, Mr. Trudeau stated that he had instructed the Crown not to appeal. The Criminal Code was also "amended to remove these technical objections." ${ }^{\text {"65 }}$

Similarly, to ensure the accused equality before the law and a fair hearing in accordance with the principles of fundamental justice as provided for in the Canadian Bill

William G. Morrow, "The Judge as Law-Maker" (Address to the University of Alberta, Edmonton, Alberta, 1 February 1972) [unpublished].

162. (Unreported April 8, 1968).

163. William G. Morrow, "Riding Circuit in the Arctic" (1974) 58:5 Judicature 236 at 240.

164. When Justice Morrow was appointed to the bench in 1966 there were only fifteen members in the Northwest Territories bar: unidentified newspaper article (19 August 1966).

165

Supra, note 163. 
of Rights, Justice Morrow construed what was then section 563(1) of the Criminal Code as permitting the Crown only two peremptory challenges, instead of four as provided for in the Code. ${ }^{166}$ In the Northwest Territories, a jury was composed of only six jurors rather than twelve. Only the number of defence challenges and Crown stand-bys had been reduced in the Code in light of the smaller jury.

Justice Morrow believed that the three most powerful tools in administering justice in the north were the independence of the Court, the jury system, and a judge's discretion in sentencing.

\title{
1. Independence of the Court
}

Justice Morrow's view of the Court was very much a traditionalist one. Notwithstanding the many places he was forced to hold court, he went to great lengths to preserve appearances and formalities. He guarded the integrity and independence of his Court fiercely. In the judgment he released in Re Paulette, after the Crown served notice of its application for a writ of prohibition, he said: ${ }^{167}$

\begin{abstract}
I am certain that this is the first time in the history of Canadian jurisprudence, the first time since Confederation, when one superior court judge has been placed under attack by another superior court judge of equal status. To me, this is such a breach of what I choose to call constitutional etiquette that I feel I must yield to the pressure I feel being put on me by the Govemment so as to at least give my interim judgment, now, rather than later, which would have been better practice. I am moved to do this against my normal inclination, which would be to not back down, because I feel that it is my constitutional duty to let the people within my jurisdiction and their Parliament know what is happening and so that they will have their Judge's side of the sorry story.
\end{abstract}

During an inquest into the crash of a mercy flight, the coroner ruled that evidence that the pilot had eaten the flesh of a passenger should be introduced and refused to go in camera to hear the evidence. In hearing an application for prohibition as a result of the coroner's rulings, Justice Morrow was reported as saying "that reporters 'sometimes get under your skin' but they are the final guardians of democracy that keep the courts honest." 168

There was, however, one occasion when Justice Morrow believed the media had gone too far. An editorial entitled, "A double standard of justice in the Northwest Territories?", in the News of the North, the largest newspaper in the territories at the time, made accusations that every effort had been made to cover up the case of a prominent public official charged with impaired driving.

In what was an unusual move for a judge, Justice Morrow released the following statement: ${ }^{169}$

The many obvious misstatements of fact and the scandalous attack not only on myself but on all those associated with the trial discussed in the article including the Clerk, the Crown Attomey and the Defence

Counsel has placed me in the position where, failing the publication of a suitable apology and retraction[,]

\footnotetext{
106. R. v. Pudlook, [1972] 6 W.W.R. 641.

167. [1973] 6 W.W.R. 97 at 100.

168. The Edmonton Journal (1 March 1973).

169. News of the North (21 May 1975).
} 
I have no alternative but to defend the honour of the Court by instructing the Crown Attomey's office to bring contempt proceedings at the earliest possible date. A request is also being forwarded to the Minister of Justice to appoint a Supreme Court Justice from any of the provinces to hear the matter.

Prior to releasing the statement, Justice Morrow had attempted to resolve the matter by arranging for a meeting, which he himself did not attend, between the publisher and all the people involved in the case. The News of the North published Justice Morrow's statement under the heading "Judge Morrow issues ultimatum to publisher." It did not, however, issue an apology or a retraction. ${ }^{170}$

Colin Alexander and his Yellowknife Publishing Company were subsequently convicted of contempt as a result of the editorial and a cartoon which had appeared in a subsequent issue of the paper. ${ }^{171}$ According to another local newspaper: ${ }^{172}$

The cartoon showed a lawyer speaking to an Eskimo saying: 'Oh no, he's actually quite lenient with your kind of people.' In the next frame, a judge is leering down at the Eskimo from his seat on the bench saying: 'I sentence you to a 100 years in jail for contempt of court.' In the final frame, the Eskimo and lawyer are walking away together and the lawyer is saying: 'So much for the double standard of justice.

\section{Jury System}

Justice Morrow believed it was critical for an accused, in the north, to be judged by his peers: ${ }^{173}$

... I look upon the jury as the big safety outlet -- preventing what otherwise might be a harsh and unjust verdict if our white-man's law was applied literally to the local situation.

$R$. v. Shooyook, ${ }^{174}$ or the "witchcraft" case as Justice Morrow has aptly called it, in which he defended one of the co-accused, illustrates the value of a jury. The case involved Eskimo customs and beliefs and a crime, according to the law, arising therefrom. In the summer of 1965, the Fort Ross group of Eskimos, which consisted of three families, fled their camp because they were afraid of one of their members, Soosee, the mother of the co-accused, Aiyaoot. The Eskimos feared she was possessed and that she was trying to spread evil spirits when she blew on them. She had also attempted to kill her husband. They tied Soosee up and went to an island a short distance away to observe her: Soosee broke loose of her restraints and went about destroying the camp. Four members of the group were sent back to try and scare her away and failing that, to kill her. She continued to approach notwithstanding the warning shots fired by Shooyook and Aiyaoot; eventually shots fired by Shooyook killed her.

An apology was published in the News of the North on July 5, 1975, after the publisher and his company were convicted of contempt of court. The apology was voluntary and not part of the sentence which was imposed.

A.G. Canada v. Alexander and Yellowknife Publishing Company, [1975] 6 W.W.R. 257.

The Yellowknifer (3 July 1975). The cartoon is reproduced in the case repor, ibid. at 276.

William G. Morrow, "Role of a Northem Judge in Civil and Criminal Cases" (Address to University of Westem Ontario, London, Ontario 4 November 1974) [unpublished].

(Unreported 1966). Since the decision was not reported and the authors were unable to speak with any of the participants in the case, they have had to rely largely on the accounts of the case in the media. While the authors have endeavoured to portray the case accurately, Justice Morrow, in his personal papers, has cast some doubt on the accuracy of the coverage. 
According to psychiatric evidence at the trial, "[i]n the minds of the Eskimos ... Soosee constituted a fearful, incomprehensible force." ${ }^{175}$ The Eskimo belief in the supernatural and the necessity of survival dictated that they kill one of their own. A complete record of the incident had been kept by Shooyook's father. It was that record which would give rise to the charge of capital murder against his son and Soosee's son. The police were informed of the events that had transpired during the summer when the Royal Canadian Mounted Police arrived in the fall of that year to pick up the children to go to school in Inuvik.

The case was unusual in other ways as well. Justice Sissons permitted photography and tape recording during the trial. The media hired an Eskimo to carry reports of the trial, by dogsled, the sixty miles from Spence Bay where the trial was held to a DEW line station where the reports could be transmitted to southern centres. ${ }^{176}$ The jury consisted of both white people and Eskimos; it was also the first time there was a woman juror in the territories. ${ }^{177}$

The jury returned with a verdict of not guilty with respect to Aiyaoot and a verdict of manslaughter with respect to Shooyook. Justice Sissons gave Shooyook a two year suspended sentence.

The jury was able to deliver a just verdict whereas a judge sitting alone would have been, in law, required to find the accused guilty of murder -- an unjust verdict. Moreover, a conviction of murder at that time carried the death sentence.

Justice Morrow also had experiences where, as a judge, he would have been required to convict, but where the jury acquitted, echoing his belief that a just verdict had been achieved in light of the surrounding circumstances. ${ }^{178}$ Justice Morrow called upon natives for jury duty as often as possible. The sparse population coupled with the requirement that jurors had to be fluent in English made it more difficult.

\section{Discretion in Sentencing}

It is perhaps in his sentencing practices that Justice Morrow was most frequently misunderstood, having been labelled on more than one occasion as "soft on natives". Justice Morrow described sentencing in the north as follows: ${ }^{179}$

175. The Edmonton Journal (6 May 1971).

176. The Edmonton Journal (15 April 1966).

17. Women were prohibited from serving on juries until 1965: Jury Ordinance, Amendment, O.N.W.T. 1965 (2nd), c. 6.

178. During Justice Morrow's time in the north there were four all-native juries including one all-women jury. Rape was the charge in each of the cases. The jury acquitted on all four occasions. Justice Morrow believed that in so finding the juries were influenced by their customs and beliefs: William G. Morrow, Address (to a gathering of Southam Editors) as reported by The Edmonton Journal (20 June 1974).

William G. Morrow, "The Criminal Justice System and its Application to the Problems of Native Peoples in the Territories" (The George M. Duck Lecture, University of Windsor, Windsor, Ontario, 24 March 1975) [unpublished]. 
I think that in the Northwest Territories, more than in any other part of Canada, I have a tougher problem than most trial judges, because I am dealing with more than just the normal sentencing problems. I am dealing perhaps with the clash of social cultures. ... I think I have a heavier burden than most trial judges in an attempt to hit the proper sentence, so that the impact of the culture that is taking over your country from the south is not too harsh, and yet at the same time it must be in a way which educates people ...

In 1960, the newly constituted Court of Appeal of the Northwest Territories ${ }^{180}$ sat in Yellowknife at the urging of Justice Morrow. One of the appeals which the Court heard was a sentence appeal in $R$. v. Ayalik. ${ }^{181}$ Justice Morrow had been retained to represent the accused who had been charged with murder after he killed a police officer while escaping custody following his arrest for a liquor related offence. In dismissing the appeal, the Court cited its recent decision in $R$. v. Bompas ${ }^{182}$ concerning the principles which govern such appeals: ${ }^{183}$

In view of these decisions one is led on appeal from a sentence imposed by a trial judge to inquire as to what principle he has overlooked in arriving at what would be a fit and adequate sentence. It is clearly recognized that if the sentence imposed is so inadequate as to show that he did not consider the nature of the crime as it is regarded by parliament in fixing the minimum and maximum limits of punishment he must have failed, and again if the sentence shows that he did not consider the circumstances of the case, he again failed to apply the proper principle.

\section{MacDonald, J.A., speaking for the Court, also said: ${ }^{184}$}

However it should be noted that in the present case the learned trial judge had a distinct advantage over the members of the court for with his wide experience in the far-flung areas of the extensive jurisdiction of the trial division of this court he has knowledge of local conditions, ways of life, habits, customs and characteristics of the race of people of which the accused is a member.

This decision would be relied upon in many cases concerning sentencing in the future. There were also several guidelines which Justice Morrow relied on "in an attempt to soften the blow to be expected from the application of southern-made law": ${ }^{185}$

a) [s]pecial treatment especially in sentencing is often applied - not to favour a native so much as to make an adequate adjustment to ensure he has been treated equally - this requires flexibility - depending on life span, and the degree of local sophistication in a given community[;]

b) [s]ocial and cultural upheaval resulting from close proximity to some resource development such as a mine has to be allowed for[;]

c) [e]ducational differences as between the older uneducated and the younger school-educated[; and]

d) [t]he southem intrusion is not hitting all the people at the same time or in the same degree.

Justice Morrow did not believe in long sentences for native people, particularly Eskimos, undoubtedly because of their even more primitive way of life. He frequently said that he would give an Eskimo offender one-half of the sentence he would give a white offender for the same crime because the life expectancy of an Eskimo was approximately one-half of that of a white person.

180. An Act to Amend the Northwest Territories Act, S.C. 1960, c. 20, s. 6.

181. (1960), 33 W.W.R. (N.S.) 377.

182. (1959), 27 W.W.R. (N.S.) 399, 30 C.R. 45,123 C.C.C. 39.

183. Supra, note 180 at 378.

184. Ibid.

185. William G. Morrow, "Taking Justice to the People" (Address at Yellowknife, Northwest Territories, 20 June 1975) [unpublished]. 
Justice Morrow was vigilant in his efforts to avoid sending native people to southern penitentiaries which were ill-equipped to deal with them. ${ }^{186}$ A first offender usually received a suspended sentence. He also tried to impose a sentence of less than two years whenever possible. Justice Morrow saw it as harsh and cruel treatment to send them to a hostile environment, among people who did not speak their language, and isolated from their way of life. He also believed it operated to infect them with a criminal element unknown in their communities. In one instance, after a person returned home following time spent in a penitentiary, the first case of safe-cracking and forgery occurred in his community. ${ }^{187}$

Ultimately, Justice Morrow believed he was equalizing rather than favouring. While criticism of his sentencing practices made itself felt, he persevered, believing that his insight into the surrounding circumstances necessitated such a judicial approach.

\section{E. INQUIRIES}

Justice Morrow was also involved in a number of inquiries during his years as a judge, which concerned the impropriety of public officials -- this time as commission head. ${ }^{188}$ In 1967, he was appointed to investigate the administration of justice in the Hay River area, as well as in the territories as a whole. The inquiry was as result of allegations made by the local newspaper, Tawpe, that court proceedings were not open to members of the public, efforts had been made to impede the press in reporting on court proceedings, and people were not treated equally by the courts:

While Justice Morrow found that the allegations were unfounded, "he found numerous instances of what he called attitudes of indifference that disregarded one of the fundamentals of the administration of justice, 'namely, that justice must not only be done but must appear to be done. "'189

In summarizing what he believed to be the correct approach to northern troubles, Justice Morrow stated in his report: ${ }^{190}$

It may be all right to take young children from the teepee and from the igloo and teach them the three ' $R$ 's' and carry them along through high school, so that we can point with pride to how they have become educated. It is certainly wrong[,] I believe[,] to stop there and expect them to go back to the teepee or the igloo with their diplomas and pick up where they left off. Job training is a must and it may be necessary to manufacture jobs. The money that is being used and that certainly will be used for welfare payments and to staff our jails ... would be better used to create jobs if for no other reason than

The territorial govemment assumed the responsibility of operating the jail and penal system with the enactment of the Corrections Ordinance, O.N.W.T. 1973 (1st sess.), c. 2. As a result, people in the Northwest Territories who were sentenced to penitentiary terms would serve their sentences in the north rather than in southem institutions. William G. Morrow, "Adventures in Administering Justice in the North" (Address to University of Saskatchewan, Saskatoon, Saskatchewan, 18 November 1971) [unpublished].

188. Justice Morrow headed inquiries involving the civic affairs of Calgary and Edmonton in 1970-71 and 1974, respectively.

189. The Toronto Globe and Mail (16 March 1968).

190. William G. Morrow, "Inquiry re Administration of Justice in the Hay River Area in the Northwest Territories" (1968) Report at 99. 
to restore self-reliance and pride to the native people. In other words, let it be spent before, not after, for prevention, not detention.

As a result of the inquiry, Justice Morrow believed that the most significant factor in the rate of incarceration of aboriginal peoples was alcohol which he largely attributed to "southern encroachment". At that time, liquor offences overwhelmingly constituted the preponderance of violations. As he expressed, "these figures convince me rather than evidence of criminality, it was an indication of a serious social or cultural breakdown." 191

Of the many of Justice Morrow's 74 recommendations which were eventually implemented by the Trudeau government, he was most pleased to see the adoption of a Legal Aid scheme, which later served as a model in many provinces. As the then Minister of Justice, The Right Honourable John N. Turner, recalls: ${ }^{12}$

We were impressed by Mr. Justice Morrow's wish to allow equality of access to the law in the north where a good many of the people who sought legal remedies, either criminal or civil, were without means. We implemented that in the north at the same time we negotiated with the provinces a Legal Aid scheme, federal and provincial.

\section{ENDINGS}

During his years in the north, Justice Morrow achieved much of what he had set out to do. He brought to the Court an empathetic approach in the midst of an era of rapid change. He endured recurring criticism in his treatment of native offenders, at times seen as tempered paternalism. He stretched the law, bent the law, and shaped the law without breaking its spirit or exceeding his jurisdiction. In continuing Justice Sissons' tradition of taking justice to the people he preserved what continues to be a fundamental principle in the administration of justice in the north.

Towards the end of his tenure, Justice Morrow began to witness an èmerging sophistication in the north. The growth and development in the communities began to be reflected in the cases before the Court; not only ravaged by alcohol but now by drugs. The judicial response which was in keeping with the views shared by the people -- elders in the communities -- saw rigorous sentences being imposed much like in the south. There were fewer and fewer people whose conduct could be explained as something other than criminal; less and less would the Court serve as a buffer between divergent cultures.

In Mr. Turner's view, one which is shared by many, Justice Morrow: ${ }^{193}$

... relinquish[ed] a very successful practice in Edmonton where he was well-established and well-regarded and then spent a decade of his life as a pioneer in the development of the law, in the frontier of our country. Those are our unsung heroes and I think not enough can be said for the sacrifice and the deprivation and the time and the complete absorption with the law and with the community that Bill Morrow put to that job. And you know, if you want to rank, within my lifetime, twenty-five heroes across the country, I'd put Bill Morrow right up there. 
Justice Morrow's widow, Genevieve, recalls that they had mixed emotions about his appointment to the Appellate Division of the Supreme Court of Alberta in 1976. They had a beautiful house which they had laboured to build, the outdoors had been appealing with its unequalled opportunities for hunting and fishing, there had been official functions which occasioned meeting many dignitaries and royalty, there were many friends -- it had become home. As this was the third time Justice Morrow had been approached, they felt it was time to accept.

Several years earlier they had both been more ready to leave. The strains of political infighting, largely centered, in Justice Morrow's view, on the independence of the Court, the stress of the sheer isolation on a solitary judge in so remote a location, and on his family, had disheartened them at times. Mr. Turner had prevailed upon Justice Morrow to remain until a suitable replacement could be found, which was complicated by the small bar in the territories.

The adjustment in progressing from a trial judge to an appellate judge is nearly as unsettling as the transition from an advocate to an adjudicator. There are many differences between a trial court and an appellate court: ${ }^{194}$

... as compared to trial, a trial judge is free in his courtroom. He doesn't have to look over his shoulder. He's lonely, isolated, but he has control. In the Court of Appeal, he's only one of three or five: indeed he's part of a larger group and ... it isn't his courtroom. Even if he's the presiding judge he doesn't run it and he may have to persuade his colleagues and is subject to discussion and persuasion. It's quite a different life than a judge's courtroom and there are no real people there, it's all paper... . I think most appellate judges who have been trial judges miss that. On the other hand you don't have to make these decisions on your own... .

Justice Morrow was likely more at home in a trial court -- in the thick of things. Yet he still found appellate work interesting and challenging because of his keen interest in the law. As an appellate judge one is also conscious of the fact that one's decision may be the law for many years to come. Justice Morrow was a team player and an invaluable colleague during his years on the Court of Appeal. His untimely death in August of 1980 was felt by many.

\section{POSTSCRIPT}

In looking to the future on one occasion, Justice Morrow urged those entering the practice of law: ${ }^{195}$

... to use the profession to help protest injustice, not just to earn a comfortable living. ... A free society depends on the lawyers who will stand up for free and just causes and judges are only as good as the lawyers they began as ... . You can't all work in the north, but you can help to champion personal liberties and preserve human dignity anywhere in this country.

Whether or not he realized it, Justice Morrow's words and the convictions they voiced were exemplified in his own career.

195. William G. Morrow, Convocation Address (Faculty of Law, Dalhousie University, Halifax, Nova Scotia) as quoted in The Chronicle-Herald (13 May 1972). 
It has been said that "there is a better thing on earth than wealth, a better thing than life itself; and that is, to have done something before you die, for which good [people] may honour you... ."196 It is fitting on the tenth anniversary of his passing that Justice Morrow be so honoured. 